\title{
Experimental study of the transfer of transuranium nuclides in marine decapod crustaceans
}

\author{
J. C. Guary*, S. W. Fowler \\ IAEA, International Laboratory of Marine Radioactivity, 2, Avenue Prince Hereditaire Albert, MC-98000 Monaco
}

\begin{abstract}
A series of laboratory radiotracer experiments was carried out to examine the biokinetics of the transuranium nuclides plutonium, americium and neptunium in decapod crustaceans. Crabs Carcinus maenas exposed to ${ }^{237} \mathrm{Pu}$ or ${ }^{241} \mathrm{Am}$ in seawater reached whole body concentration factors (CF) of 75 and 145, respectively, after $8 \mathrm{~d}$. Highest concentration factors for individual tissues were those for gills $(\mathrm{CF}=960$ for Am, 340 for $\mathrm{Pu}$ ). For both radionuclides, about $70 \%$ of total body burden was associated with the exoskeleton in which $\mathrm{Am}(\mathrm{CF}=240)$ was enriched relative to $\mathrm{Pu}(\mathrm{CF}=70)$ Elimination of each radionuclide was relatively rapid with biological half-times of 45 and $55 \mathrm{~d}$ for Am and $\mathrm{Pu}$, respectively, for the slow release compartment. Because much of the accumulated body burden was associated with the exoskeleton, moulting strongly influenced elimination. ${ }^{237} \mathrm{Pu},{ }^{241} \mathrm{Am}$ or ${ }^{237} \mathrm{~Np}$ ingested with labelled food by various decapod species were initially excreted with the feces, followed by loss from a soluble radionuclide pool within the animal. Absorption efficiencies for ingested transuranics ranged from 10 to $40 \%$ with highest values in the largest decapods (C. maenas and Cancer pagurus) examined. Initially, absorbed radionuclides were mostly contained in the hepatopancreas; however, there is evidence for internal transfer of transuranics to other tissues, particularly those associated with the exoskeleton. Such high assimilation efficiencies differ markedly from the few tenths or hundredths of a percent typically found in vertebrate species and thus highlight the ability of decapods to assimilate and retain large fractions of transuranium nuclides incorporated in their prey.
\end{abstract}

\section{INTRODUCTION}

Transuranium nuclides have been contaminants in the marine environment for more than 3 decades. Atmospheric fallout from nuclear testing is the principal pathway by which these radionuclides have entered the sea (Perkins \& Thomas 1980, Edgington 1981), although considerable quantities have been directly released into the coastal environment via nuclear fuel reprocessing wastes (Hetherington 1976, Pentreath 1981). Plutonium-239, americium-241 and neptunium-237 are the 3 long-lived transuranium nuclides of principal interest. At present the plutonium inventory is greater than that of any other transuranium element (Watters et al. 1983); consequently it has received the most attention in marine radioecological studies (see reviews by Beasley \& Cross 1980 and Pentreath 1981). Interest in studying ${ }^{241} \mathrm{Am}$ has increased due mainly to 2 facts: (1) its inventory will

\footnotetext{
- Present address: Institut National des Techniques de la Mer, BP 324, F-50103 Cherbourg Cedex, France
}

increase in the future through the in situ decay of ${ }^{241} \mathrm{Pu}$ (Day \& Cross 1981), and (2) in some instances americium may be more bioavailable in the environment than plutonium (Pentreath 1981). Neptunium-237 has also received some attention because of its very long physical half-life $\left(\mathrm{T}_{1 / 2}=2.2 \times 10^{6} \mathrm{yr}\right)$ and its projected increase in marine environments due to radioactive wastes from spent nuclear fuel reprocessing (Schulz \& Benedict 1972, Bowen 1974) and in situ generation from ${ }^{241} \mathrm{Am}$. Several studies have examined the bioaccumulation and transfer of these radionuclides (principally plutonium) in a variety of marine species, and recent literature reviews show that the relatively small amount of data on americium and neptunium in aquatic biota does not provide an adequate basis for comparison with the corresponding plutonium data base (Beasley \& Cross 1980, Pentreath 1981).

Since the pioneering work of Ward (1966) on the accumulation of ${ }^{239} \mathrm{Pu}$ from water by the European lobster, a limited number of laboratory and field studies have examined the role of crustaceans in the transfer and transport of plutonium (Fowler et al. 1975, Guary et al. 1976, Fowler \& Guary 1977, Pentreath 1981), 
americium (Pentreath 1981, Fisher et al. 1983, Carvalho \& Fowler 1984, 1985, Miramand et al 1989) and neptunium (Guary \& Fowler 1977, 1978, Fowler \& Aston 1982). These 3 radionuclides are accumulated to different degrees at both the whole organism and tissue level. For example, in some species of shrimp and crabs (Guary 1980) plutonium appears more available for uptake from seawater than neptunium. Certain tissues of benthic decapods show enhanced uptake of americium relative to plutonium (Pentreath 1981). Furthermore, some benthic decapods such as crabs and lobsters have an ability to assimilate a large fraction of the plutonium or americium ingested with their food (Fowler \& Guary 1977, Fowler \& Carvalho 1985). Given the importance of these crustaceans in marine food chains, and to increase the existing transuranic data base, we have undertaken a comparative laboratory study of the transfer of plutonium, americium and neptunium from water and food to some representative decapod crustaceans. The results of these experiments are then discussed with respect to the existing literature to draw some general conclusions concerning metabolic mechanisms for uptake, storage and excretion and transuranium nuclides in marine decapods.

\section{MATERIALS AND METHODS}

Radiotracers and counting techniques, ${ }^{237} \mathrm{Pu},{ }^{241} \mathrm{Am}$ and ${ }^{237} \mathrm{~Np}$ were used singly as radiotracers in the experiments. The advantages of using these tracers have been described previously, together with counting techniques such as gamma spectrometry using a NaI (T1) well-type scintillation detector for ${ }^{237} \mathrm{Pu}$ and $241 \mathrm{Am}$, and the thick source alpha particle detection technique for ${ }^{237} \mathrm{~Np}$ (Fowler et al. 1975, Fowler \& Guary 1977. Guary \& Fowler 1977, 1981). The efficiencies of the measurements were 40,28 and $100 \%$ for ${ }^{237} \mathrm{Pu}$,
${ }^{24 \mathrm{I}} \mathrm{Am}$ and ${ }^{237} \mathrm{~Np}$ respectively. In most all cases, the ${ }^{237} \mathrm{Pu}$ tracer solution was adjusted to the reduced oxidation state (III + IV) before being added to seawater (Fowler et al. 1975). Although the final oxidation state in the seawater media was not tested, because of rapid exchange reactions it is unlikely that its biokinetic behaviour would be different from the oxidized couple (V + VI) (Sibley \& Sanchez 1986).

Experimental conditions. Two types of experiments were conducted with different species of crustaceans:

Uptake and elimination of ${ }^{237} \mathrm{Pu}$ and ${ }^{241} \mathrm{Am}$ from seawater and elimination in the shore crab Carcinus maenas. Conditions of labelling and feeding have been described in detail elsewhere (Guary 1980) and are summarized in Table 1. Briefly, 8 crabs were exposed to the radionuclide in $10 \mathrm{l}$ of tracer-labelled seawater which had been previously filtered through cotton to remove large particles. Each crab and aliquots of the radioactive seawater were periodically removed from the aquaria and counted by gamma spectrometry to measure radionuclide content during the $8 \mathrm{~d}$ period. In order to assess the relative uptake over time, the data were used to compute concentration factors (CF) which are defined as the radioactivity (dpm) per g animal wet weight divided by the radioactivity in an equal weight $(1 \mathrm{ml})$ of water. At the end of the bioaccumulation phase, 4 crabs were dissected to measure radioactivity in different tissues, and the remaining 4 individuals were transferred to running seawater aquaria to follow depuration of the radionuclide.

During the loss phase, crabs were periodically counted for radionuclide content and replaced in the seawater aquaria for further loss. Crabs also received daily rations of worms or mussels to ensure good health. Any uneaten food was quickly removed from the aquaria to avoid fouling the water. Radionuclide elimination was expressed as the percentage of the initial radioactivity remaining in the organism and

Table 1 Carcinus maenas. Summary of experimental conditions for uptake from seawater (accumulation) and elimination of ${ }^{237}$ Pu and ${ }^{241} \mathrm{Am}$ by shore crab

\begin{tabular}{|c|c|c|c|c|}
\hline & \multicolumn{2}{|c|}{ Accumulation } & \multicolumn{2}{|c|}{ Elimination } \\
\hline & ${ }^{237} \mathrm{Pu}$ & ${ }^{241} \mathrm{Am}$ & ${ }^{237} \mathrm{Pu}$ & ${ }^{241} \mathrm{Am}$ \\
\hline No. of individuals & 8 & 8 & 4 & 4 \\
\hline Average wet weight ( \pm 1 SD) & $\begin{array}{l}19.4 \mathrm{~g} \\
( \pm 2.2)\end{array}$ & $\begin{array}{l}18.19 \\
( \pm 3.8)\end{array}$ & $\begin{array}{l}20.5 \mathrm{~g} \\
( \pm 1.5)\end{array}$ & $\begin{array}{l}22.3 \mathrm{~g} \\
( \pm 2.0)\end{array}$ \\
\hline $\begin{array}{l}\text { Mean radionuclide concentration in } \\
\text { water or organism" }\end{array}$ & $\begin{array}{c}50 \\
\left(\mathrm{dpm} \mathrm{ml} \mathrm{ml}^{-1}\right)\end{array}$ & $\begin{array}{c}70 \\
\left(\mathrm{dpm} \mathrm{ml}^{-1}\right)\end{array}$ & $\begin{array}{c}2200 \\
\left(\mathrm{dpm} \mathrm{g}^{-1}\right)\end{array}$ & $\begin{array}{c}5700 \\
\left(\mathrm{dpm} \mathrm{g} \mathrm{g}^{-1}\right)\end{array}$ \\
\hline Water temperature & $13^{\circ} \mathrm{C}$ & $13^{\circ} \mathrm{C}$ & $12-16^{\circ} \mathrm{C}$ & $12-16^{\circ} \mathrm{C}$ \\
\hline Duration of experiment & $8 d$ & $8 d$ & $70 \mathrm{~d}$ & $70 \mathrm{~d}$ \\
\hline $\mathrm{dpm}=16.7 \mathrm{mBq}$ & & & & \\
\hline
\end{tabular}


standard statistical methods were used to calculate biological half-times $\left(\mathrm{T}_{\mathrm{b}^{1 / 2}}\right)$ for loss of the radionuclide (Guary \& Fowler 1981). At the end of the elimination period, all the individuals were dissected to measure the residual radioactivity in tissues and to determine the distribution of both transuranic nuclides.

Transuranic element transfer via the food chain. Experiments were designed to determine the fraction of ingested ${ }^{237} \mathrm{Pu},{ }^{241} \mathrm{Am}$ or ${ }^{237} \mathrm{~Np}$ that was assimilated after a single meal as well as the distribution of the radionuclide in tissues of 5 decapod species. An adsorption (assimilation) efficiency', or percentage of each radionuclide assimilated from food was estimated by resolving the different components of the excretion curves using standard mathematical techniques (Fowler \& Guary 1977, Guary 1980). In some cases, to obtain sufficiently labelled food, small quantities ( 20 to $50 \mu$ l) of radiotracer solution were injected directly into living prey (mussels). Under these conditions, the initial loss of radioisotope from prey submerged in flowing seawater during feeding was ca $10 \%$ of the injected dose. In other cases, prey (e.g. Artemia and worms) were simply labelled by direct exposure to the radioisotopes in seawater for several days prior to the experiment (Fowler \& Guary 1977). In this way radionuclide losses to seawater during feeding were always less than $5 \%$.

Decapods of very different sizes, such as the shrimps Lysmata seticaudata and Palaemon serratus, and the crabs Pachygrapsus marmoratus, Carcinus maenas and Cancer pagurus were selected for the experiments. Body weight differences were as great as 1 to 20 between $L$. seticaudata and C. maenas, and 1 to 1000 between $L$. seticaudata and $C$. pagurus. For the gamma emitters, the ingested radioactivity was measured directly in each individual immediately after the meal. In the case of the alpha emitter ${ }^{2.37} \mathrm{~Np}$, it was estimated on the basis of the radioactivity offered, using an average ingestion efficiency. A preliminary experiment demonstrated that about $65 \%$ of the radioactivity present in the food is effectively ingested by $C$. maenas and C. pagurus; the remainder is lost to the water when the prey is masticated and ingested (Guary 1980). Following ingestion of labelled food, each individual was placed in an aquarium supplied with flowing seawater and received a daily ration of unlabelled food (Artemia, worms or mussels) until the end of the experiment. The residual radioactivity of the gamma emitters $\left({ }^{237} \mathrm{Pu}\right.$ and ${ }^{241} \mathrm{Am}$ ) was measured daily. The percentage of residual radioactivity was plotted as a function of time in order to estimate the absorption efficiency (Fowler \& Guary 1977). Likewise, the moults and feces were recovered and their gamma radioactivity measured. Several individuals were dissected during the experiments to determine the concentration and distribution of the radionuclides in the tissues. The elimination of the absorbed ${ }^{237} \mathrm{~Np}$ was followed by making serial dissections of specimens during the experiment and radioanalyzing ${ }^{237} \mathrm{~Np}$ in their tissues by the thick-source alpha particle detection technique (Guary \& Fowler 1977). A summary of the conditions for each assimilation experiment is presented in Table 2 .

The absorption and the transfer of ${ }^{241}$ Am after multiple feedings with labelled meals was studied in Carcinus maenas. Female crabs ( $20 \pm 4 \mathrm{~g}$ average weight) were selected to facilitate measurements of wholebody radioactivity in vivo by the method described previously. Every week individuals received a mussel labelled by injection of ${ }^{241} \mathrm{Am}\left(5.4 \times 10^{5} \mathrm{dpm}\right)$ into the visceral gland. A preliminary experiment demonstrated that about $20 \%$ of the amount injected was either lost to the water or adsorbed on the mollusc shell and therefore was not available to the crabs. After each radioactive meal crabs received an unlabelled mussel and, 7 to $8 \mathrm{~d}$ later, they ingested the next radioactive ration. The residual radioactivity of each crab was measured periodically during the $76 \mathrm{~d}$ experiment. After each radioactive ration, the ingestion efficiency and ${ }^{241}$ Am transfer efficiency (for food only) in whole crabs and hepatopancreas were calculated as follows:

$$
\begin{aligned}
& \text { Ingestion efficiency }=\frac{\text { radioact. ingest. by crabs }}{\text { radioactivity in food }} \times 100 \\
& \text { Transfer efficiency } \\
& \text { (food) } \\
& \frac{\text { conc. of }{ }^{241} \mathrm{Am} \text { in crab after feeding }\left(\mathrm{dpm} \mathrm{g} \mathrm{g}^{-1}\right)}{\text { conc. of }{ }^{241} \mathrm{Am} \text { in prey }\left(\mathrm{dpm} \mathrm{g}{ }^{-1}\right)} \times 100
\end{aligned}
$$

The transfer efficiency was calculated for the hepatopancreas assuming that about $75 \%$ of the ingested ${ }^{241} \mathrm{Am}$ was accumulated in that organ and that it represents about 7 to $8 \%$ of the weight of the crab (Guary 1980).

To evaluate the radionuclide concentration and distribution in crab tissues, 2 individuals were dissected after the 3 rd and 5 th radioactive ration, and 6 other crabs were dissected at the end of the experiment following 10 rations of labelled mussels.

\section{RESULTS}

\section{Bioaccumulation of ${ }^{237} \mathrm{Pu}$ and ${ }^{241} \mathrm{Am}$ from seawater in Carcinus maenas}

Plutonium and americium were accumulated quite rapidly in the crab Carcinus maenas; however, equilibrium was not reached after $8 \mathrm{~d} \cdot{ }^{241} \mathrm{Am}$ appeared to have a greater affinity for crab tissue than ${ }^{237} \mathrm{Pu}$ as evidenced by concentration factors (CF) of 145 and 75 for ${ }^{241} \mathrm{Am}$ and ${ }^{237} \mathrm{Pu}$, respectively (Fig. 1). This differ- 
Table 2. Summary of experimental conditions of transuranic element transfer via the food chain following a single meal

\begin{tabular}{|c|c|c|c|c|c|}
\hline Species & $\begin{array}{c}\text { No. } \\
\text { of } \\
\text { individuals }\end{array}$ & $\begin{array}{l}\text { Average } \\
\text { wet weight } \\
\text { (g) }\end{array}$ & Food & $\begin{array}{l}\text { Mode of } \\
\text { labelling }\end{array}$ & $\begin{array}{l}\text { Range of ingested } \\
\text { radioactivity } \\
\text { (dpm ind. }^{-1} \text { ) }\end{array}$ \\
\hline \multicolumn{6}{|c|}{ Lysmata seticaudata } \\
\hline${ }^{237} \mathrm{Pu}$ & 17 & $\begin{array}{c}1.1 \\
( \pm 0.2)\end{array}$ & Artemia & 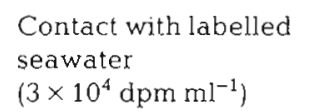 & $1-38 \times 10^{4}$ \\
\hline${ }^{241} \mathrm{Am}$ & 10 & $\begin{array}{c}1.2 \\
( \pm 0.5)\end{array}$ & $\begin{array}{l}\text { Artemia and worms } \\
\text { (Nereis) }\end{array}$ & $\begin{array}{l}\text { Contact with labelled } \\
\text { seawater } \\
\left(3 \times 10^{4} \mathrm{dpm} \mathrm{ml} \mathrm{m}^{-1}\right)\end{array}$ & $1-22 \times 10^{4}$ \\
\hline \multicolumn{6}{|c|}{ Palaemon serratus } \\
\hline${ }^{237} \mathrm{Pu}$ & 4 & $\begin{array}{c}4.0 \\
( \pm 0.5)\end{array}$ & Artemiā & $\begin{array}{l}\text { Contact with labelled } \\
\text { seawater } \\
\left(3 \times 10^{4} \mathrm{dpm} \mathrm{m} \mathrm{l}^{-1}\right)\end{array}$ & $1-11 \times 10^{4}$ \\
\hline${ }^{241} \mathrm{Am}$ & 5 & $\begin{array}{c}3.4 \\
( \pm 0.8)\end{array}$ & $\begin{array}{l}\text { Artemia and worms } \\
\text { (Nereis) }\end{array}$ & $\begin{array}{l}\text { Contact with labelled } \\
\text { seawater } \\
\left(1.8 \times 10^{4} \mathrm{dpm} \mathrm{m} \mathrm{m}^{-1}\right)\end{array}$ & $1-11 \times 10^{4}$ \\
\hline \multicolumn{6}{|c|}{ Pachygrapsus marmoratus } \\
\hline${ }^{241} \mathrm{Am}$ & 6 & $\begin{array}{c}4.1 \\
( \pm 0.9)\end{array}$ & Mussels & $\begin{array}{l}\text { Injection in digestive } \\
\text { gland }\left(15 \times 10^{4} \mathrm{dpm}\right)\end{array}$ & $4-5 \times 10^{4}$ \\
\hline \multicolumn{6}{|c|}{ Carcinus meanas } \\
\hline${ }^{237} \mathrm{Pu}$ & 12 & $\begin{array}{c}12.0 \\
( \pm 2.0)\end{array}$ & Worms (Nereis) & $\begin{array}{l}\text { Contact with labelled } \\
\text { seawater } \\
\left(2 \times 10^{4} \mathrm{dpm} \mathrm{m} \mathrm{m}^{-1}\right)\end{array}$ & $1-8 \times 10^{4}$ \\
\hline${ }^{241} \mathrm{Am}$ & 4 & $\begin{array}{c}18.2 \\
( \pm 4.0)\end{array}$ & Worms (Nereis) & $\begin{array}{l}\text { Contact with labelled } \\
\text { seawater } \\
\left(2 \times 10^{4} \mathrm{dpm} \mathrm{m} \mathrm{m}^{-1}\right)\end{array}$ & $4-20 \times 10^{4}$ \\
\hline \multirow[t]{2}{*}{${ }^{237} \mathrm{~Np}$} & $5(9)$ & $\begin{array}{c}19 \\
( \pm 2)\end{array}$ & Mussels & $\begin{array}{l}\text { Injection in digestive } \\
\text { gland }\left(3 \times 10^{3} \mathrm{dpm}\right)\end{array}$ & $-3 \times 10^{3}$ \\
\hline & $4(\delta)$ & $\begin{array}{c}43 \\
( \pm 3)\end{array}$ & Worms $\left(\right.$ Nereis) ${ }^{a}$ & $\begin{array}{l}\text { Contact with labelled } \\
\text { seawater } \\
\left(2.2 \times 10^{3} \mathrm{dpm} \mathrm{m} \mathrm{m}^{-1}\right)\end{array}$ & $\sim 3 \times 10^{2}$ \\
\hline \multicolumn{6}{|c|}{ Cancer pagurus } \\
\hline${ }^{237} \mathrm{Pu}$ & 3 & $\begin{array}{c}640 \\
( \pm 50)\end{array}$ & $\begin{array}{l}\text { Mussels and worms } \\
\text { (Nereis) }\end{array}$ & $\begin{array}{l}\text { Contact with labelled } \\
\text { seawater }\end{array}$ & $10^{5}-3 \times 10^{6}$ \\
\hline${ }^{241} \mathrm{Am}$ & 2 & $\begin{array}{c}600 \\
( \pm 50)\end{array}$ & Shrimps (Lysmata) & $\begin{array}{l}\text { Injection into the } a b \text { - } \\
\text { dominal muscle }\end{array}$ & $2 \times 10^{6}$ \\
\hline \multicolumn{6}{|c|}{$\begin{array}{l}\text { Sixteen Nereis diversicolor were labelled for } 5 \mathrm{~d} \text { in radioactive seawater. Following exposure each worm was cut into halves. } \\
\text { Sixteen halves were weighed, dried at } 100^{\circ} \mathrm{C} \text {, reweighed, and the }{ }^{237} \mathrm{~Np} \text { concentration in one group of halves measured } \\
\left(630 \pm 20 \mathrm{dpm} \mathrm{g}^{-1} \text { wet wt). The remaining worm halves were distributed to the } 4 \text { male crabs in a ration of } 4 \text { per individual. }\right. \\
\text { Knowledge of the ingestion efficiency (see text) and the exact weight of the food allowed estimating the }{ }^{237} \mathrm{~Np} \text { ingested by } \\
\text { each crab, i.e. } 370,330,310 \text {, and } 295 \mathrm{dpm}\end{array}$} \\
\hline
\end{tabular}

ence essentially held for tissues in direct contact with the labelled seawater, and for some internal tissues (Table 3). A high ${ }^{241} \mathrm{Am}$ CF was observed in the gilis (960) and the exoskeleton (240), 3 to 4 times higher than the ${ }^{237} \mathrm{Pu} C F$ in the same tissues. The distribution of the 2 radionuclides was almost identical: 67 to $74 \%$ of the ${ }^{237} \mathrm{Pu}$ and the ${ }^{241} \mathrm{Am}$ was fixed in the exoskeleton which constitutes about $62 \%$ of the weight of the crab; 24 to $30 \%$ was fixed in the gills which only constitute 5 to $6 \%$ of the total biomass. The other tissues only fixed 2 to $3 \%$ of the radioelements accumulated by the crab.

\section{Elimination of ${ }^{237} \mathrm{Pu}$ and ${ }^{241} \mathrm{Am}$ from Carcinus maenas}

In Carcinus maenas, the elimination of both transuranic elements was biphasic and relatively rapid (Fig. 2). Americium, which was taken up by $C$. maenas to a greater degree than plutonium (Fig. 1), was eliminated more rapidly. For ${ }^{237} \mathrm{Pu}$ the compartment which turned over very slowly (i.e. 'slow release' component, $\mathrm{T}_{\mathrm{b}_{2}}$ : $55 \mathrm{~d}$ ), represented about $70 \%$ of the plutonium taken up by the crab. Approximately 25 to $30 \%$ of the plutonium was lost rapidly with a $\mathrm{T}_{\mathrm{b}_{12}}$ of only $3 \mathrm{~d}$. The equivalent rapid and slow release components for 


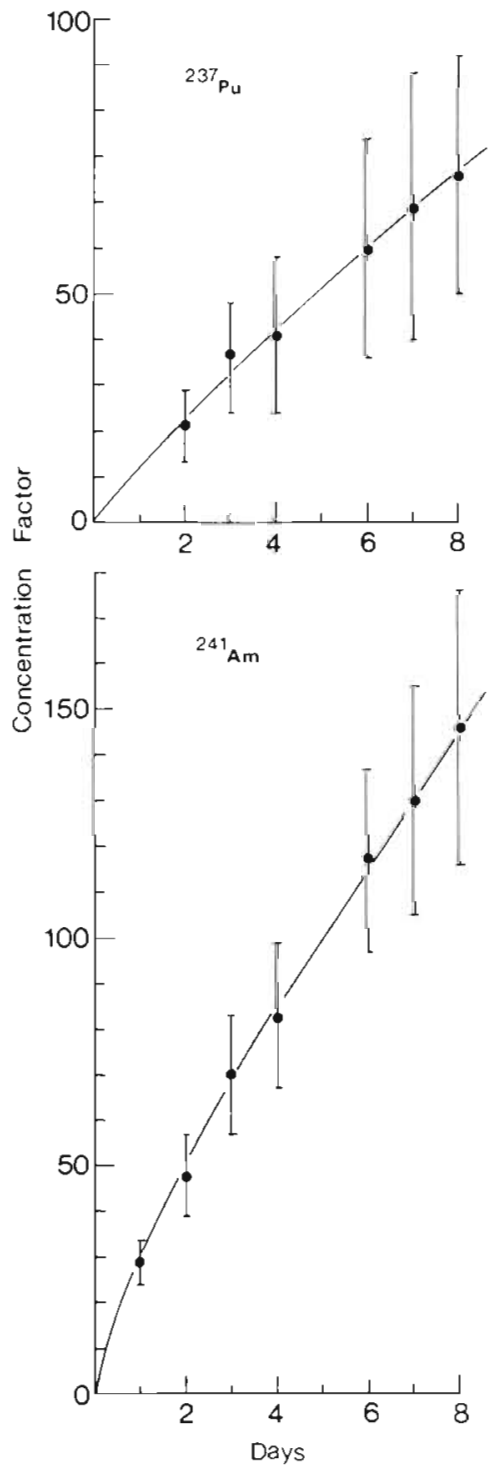

Fig. 1. Carcinus maenas. Accumulation of ${ }^{237} \mathrm{Pu}$ and ${ }^{24 i} \mathrm{Am}$ from seawater by shore crab. Values are $\overline{\mathrm{x}} \pm 1 \mathrm{SD}$
${ }^{241} \mathrm{Am}$ had half-times of 5 and $45 \mathrm{~d}$, respectively. Because such a large percentage of both the radionuclides resides in the exoskeleton (Table 3), much of the radionuclide loss from whole crabs probably occurred by simple desorption from this tissue.

Table 4 shows the distribution of the 2 radionuclides following $70 \mathrm{~d}$ of depuration. Plutonium was retained in the gill to a greater degree than in the other tissues for example, after $70 \mathrm{~d}$ of elimination, about $69 \%$ of the ${ }^{237} \mathrm{Pu}$ initially concentrated in the gills still remained. This fraction represents $56 \%$ of the total Pu retained by the crab. In contrast, comparing the data in Tables 3 and $4,{ }^{241} \mathrm{Am}$ was eliminated from the gills at almost the same rate as that for the other tissues.

\section{Tissue distribution and absorption efficiency of ingested radionuclide}

Whole body radionuclide excretion following a single ingestion of labelled food is shown in Figs. 3 to 6. The radionuclide retention curves were modelled as 2 compartment systems displaying exponential loss rates. From radioanalysis of the feces the rapid initial depuration phase observed during the first 2 to $4 \mathrm{~d}$ always corresponded to intestinal transit of the unassimilated radionuclides. Moreover, during this short period of time, 90 to ca $100 \%$ of the total amount of radionuclide eliminated from these decapods occurred through defecation. Subsequently in all cases, the proportion of radionuclides lost via the feces decreased with time reaching a minimal value that varied from one species to another. This observation suggested that, with time, excretion of the radionuclides in a dissolved form gradually became more significant. During this second phase, radionuclide elimination was slower and could be described by simple exponential curves. This period of excretion, depicted in the figures

Table 3. Carcinus maenas. Concentration factor (CF) and distribution of ${ }^{237} \mathrm{Pu}$ and ${ }^{241} \mathrm{Am}$ in tissues after $8 \mathrm{~d}$ accumulation from seawater

\begin{tabular}{|c|c|c|c|c|c|c|}
\hline \multirow[t]{2}{*}{ Tissue } & \multirow{2}{*}{$\begin{array}{l}\% \text { Total weight } \\
(\overline{\mathrm{x}} \pm \mathrm{SD} ; \mathrm{n}=8)\end{array}$} & \multicolumn{2}{|c|}{${ }^{237} \mathrm{Pu}$} & \multicolumn{3}{|c|}{${ }^{241} \mathrm{Am}$} \\
\hline & & $\mathrm{CF}$ & $\begin{array}{c}\% \text { Total body burden } \\
(\overline{\mathrm{x}} \pm \mathrm{SD})\end{array}$ & $\mathrm{CF}$ & $\begin{array}{r}\% \text { Total bc } \\
\qquad \bar{x}+\end{array}$ & $\begin{array}{l}\text { ody burden } \\
+ \text { SD) }\end{array}$ \\
\hline Exoskeleton & $62.1 \pm 3.0$ & 70 & $67.0 \pm 3.5$ & 240 & 73.8 & \pm 6.6 \\
\hline Epidermis & $2.1 \pm 0.6$ & 10 & $0.30 \pm 0.03$ & 40 & 0.4 & \pm 0.1 \\
\hline Gills & $5.7 \pm 0.3$ & 340 & $30.5 \pm 2.5$ & 960 & 24.2 & \pm 6.4 \\
\hline Hepatopancreas & $6.8 \pm 2.9$ & 2 & $0.24 \pm 0.04$ & 5 & 0.15 & \pm 0.04 \\
\hline Stomach & $1.5 \pm 0.4$ & 8 & $0.20 \pm 0.02$ & 5 & 0.04 & \pm 0.01 \\
\hline Intestine & $0.3 \pm 0.1$ & nd & - & nd & & - \\
\hline Gonads & $1.0 \pm 0.4$ & nd & - & nd & & - \\
\hline Cephalothoracic muscle & $11.4 \pm 0.9$ & 5 & $0.7 \pm 0.3$ & 5 & 0.3 & \pm 0.1 \\
\hline Pereiopod muscle & $9.1 \pm 1.9$ & 8 & $1.1 \pm 0.5$ & 25 & 1.1 & \pm 0.2 \\
\hline nd: not detected & & & & & & \\
\hline
\end{tabular}




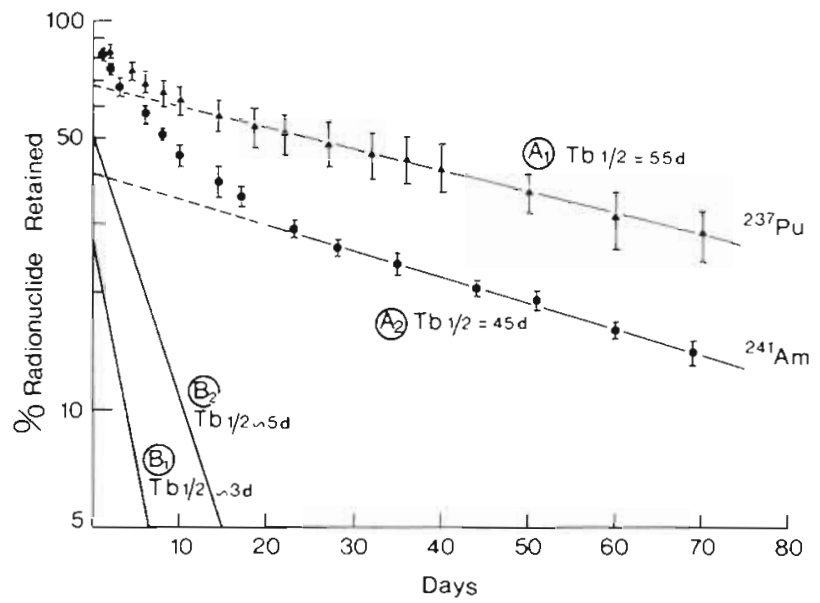

Fig. 2. Carcinus maenas. Elimination of ${ }^{237} \mathrm{Pu}$ and ${ }^{241} \mathrm{Am}$ following uptake from seawater. Values are $\bar{x} \pm 1$ SD. (A) Exponential loss from a slowly-exchanging compartment(s); (B) exponential loss from a rapidly-exchanging compartment(s) determined by curve stripping (see text)

by a solid line, represents elimination of the radionuclide fraction absorbed from food. By back-extrapolating these slow release components to time zero, plutonium, americium and neptunium absorption efficiencies in the different species of crustaceans were determined. Comparative data on averaged absorption efficiencies, whole body half-times of loss from the slow release component and percent retention of radionuclides in the digestive gland of 5 crustacean species are summarized in Table 5. Weights taken for certain nonmoulting individuals at the beginning and end of each experiment indicated that under our maintenance feeding regime, the organisms maintained an essentially constant weight throughout the study

During the experiments (Fig. 3), some shrimps Lys- mata seticaudata moulted one or more times. The moult of one individual, which at Day 4 of elimination still retained $9 \%$ of the ${ }^{237} \mathrm{Pu}$ ingested, was found to contain about $48 \%$ of its whole body radioactivity before moulting. Likewise, the moults of 2 shrimps at Days 6 and 10 contained 5 and $8 \%$, respectively, of the whole body radioactivity before moulting. Apparently some ingested ${ }^{237} \mathrm{Pu}$ can be transferred to external tissues in shrimp, particularly in the cephalothoracic region. Dissection of shrimp at various stages of elimination showed that ${ }^{237} \mathrm{Pu}$ absorbed from the food was distributed among different tissues and organs (Table 6). The hepatopancreas always contained the largest amount of absorbed ${ }^{237} \mathrm{Pu}$ (54 to $90 \%$ ), with lesser fractions of the radionuclide observed in the stomach and gut ( 3 to $13 \%$ ). After $13 \mathrm{~d}$ of elimination, the concentration of ${ }^{237} \mathrm{Pu}$ in the hepatopancreas was still much higher than in the other organs. Furthermore, a significant residual concentration of the radionuclide was also found in the gonads (Table 6).

Like ${ }^{237} \mathrm{Pu}$, about $50 \%$ of the ${ }^{241} \mathrm{Am}$ present in the shrimp at moult (Day 3) was found in the exuviae (Table 7). The ${ }^{241}$ Am percentage contained in the moult was observed to decrease during the elimination period eventually reaching zero. There were 2 groups of shrimp that differed in their stage of the moult cycle. Individuals 1 and 2 had moulted on Days 3 and 4 respectively, following ingestion of labelled food. This indicated that they ingested the contaminated ration at the end of their intermoult cycle (Stage D) which is about $20 \mathrm{~d}$ at $18^{\circ} \mathrm{C}$ (Benayoun \& Fowler 1980). Thus these shrimp ingested americium when transfer of reserves from the hepatopancreas to epidermis and exoskeleton was the highest (Travis 1955). On the other hand, the other shrimp received their single labelled ration at the beginning or middle of their intermoult

Table 4. Carcinus maenas. Concentration and distribution of ${ }^{2.37} \mathrm{Pu}$ and ${ }^{241} \mathrm{Am}$ in tissues after $70 \mathrm{~d}$ elimination in flowing seawater

\begin{tabular}{|c|c|c|c|c|c|c|c|}
\hline Tissue & $\begin{array}{l}\% \text { Total } \\
\text { werght }\end{array}$ & $10^{3} \mathrm{dpm} \mathrm{g}^{-1}$ & $\begin{array}{l}{ }^{237} \mathrm{Pu} \\
\% \mathrm{C}_{0}\end{array}$ & $\begin{array}{l}\% \text { Total body } \\
\text { burden }\end{array}$ & $10^{3} \mathrm{dpm} \mathrm{g}^{-1}$ & $\begin{array}{l}{ }^{24 !} \mathrm{Am} \\
\% \mathrm{C}_{0}\end{array}$ & $\begin{array}{c}\% \text { Total body } \\
\text { burden }\end{array}$ \\
\hline Exoskeleton & 62.3 & 0.6 & 23 & 43.9 & 1.8 & 26 & 76.6 \\
\hline Epidermis & 1.6 & nd & - & - & 0.2 & 15 & 0.15 \\
\hline Gills & 5.6 & 8.6 & 69 & 56.1 & 6.3 & 24 & 21.4 \\
\hline Hepatopancreas & 7.7 & nd & - & - & 0.04 & 29 & 0.2 \\
\hline Stomach and intestines & 1.7 & nd & - & - & nd & - & - \\
\hline Gonads & 1.7 & nd & - & - & nd & - & - \\
\hline Cephalothoracic muscle & 9.6 & nd & - & - & 0.07 & 44 & 0.4 \\
\hline Pereiopod muscle & 9.8 & nd & - & - & 0.2 & 27 & 1.2 \\
\hline Entire individual & - & 0.7 & 30 & 100 & 1.2 & 20 & 100 \\
\hline \multicolumn{8}{|c|}{$\begin{array}{l}\text { nd: not detected } \\
1 \% \mathrm{C}_{0}: \% \text { of initial concentration of the radionuclide in organs or entire individual } \\
1 \mathrm{dpm}=16.7 \mathrm{mBq}\end{array}$} \\
\hline
\end{tabular}



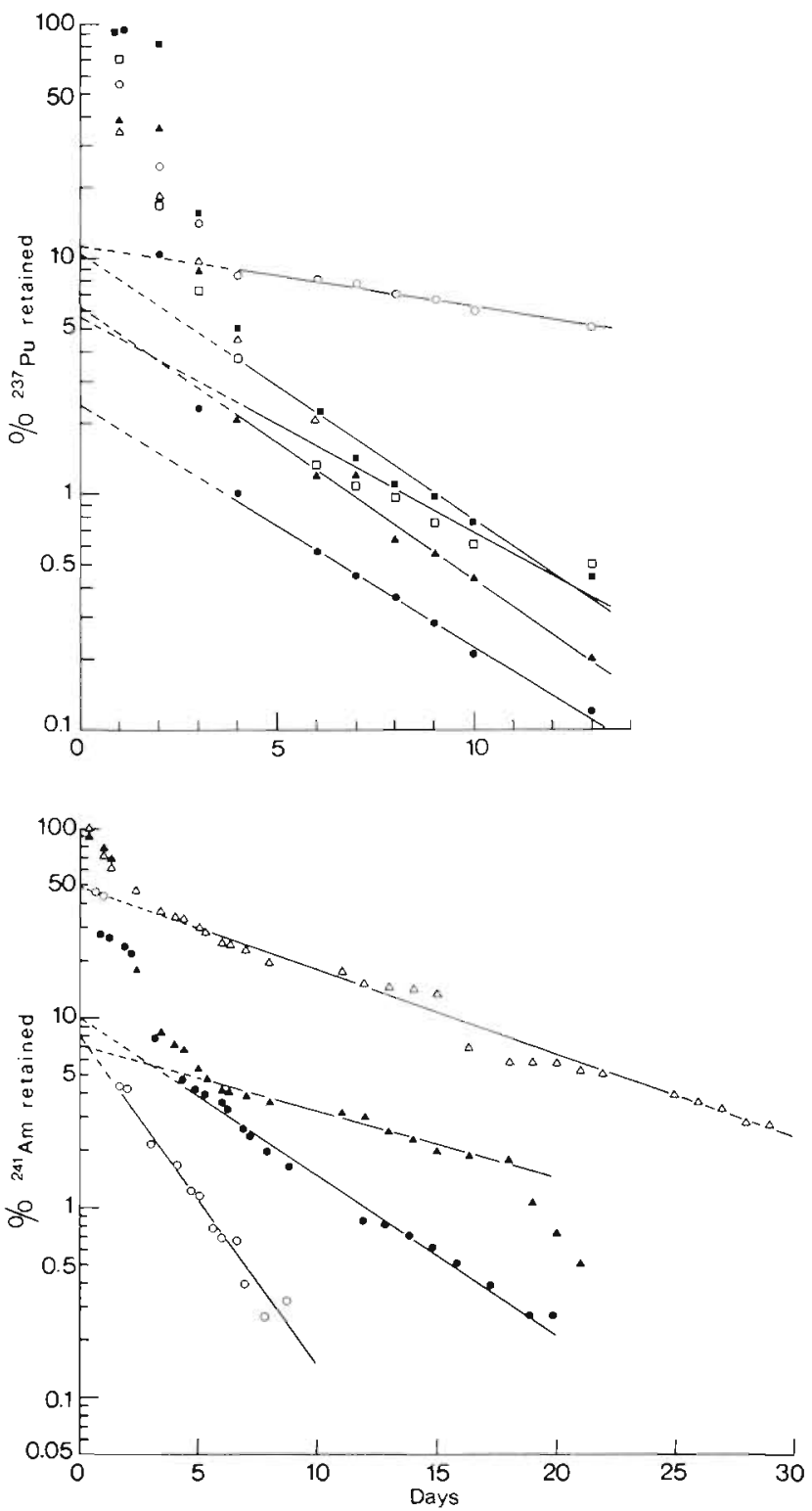

Fig. 3. Lysmata seticaudata. Elimination of ${ }^{237} \mathrm{Pu}$ and ${ }^{241} \mathrm{Am}$ from shrimp after ingestion of a single labelled meal. Each symbol represents the residual percentage of radionuclide in a single individual

cycle (Stages B or C), i.e. when crustaceans are storing reserves in the hepatopancreas. If ${ }^{24} \mathrm{Am}$ follows the same route as the organic material ingested, the major part of the radionuclide will be fixed in the hepatopancreas. Approximately 66 to $100 \%$ of the residual ${ }^{241} \mathrm{Am}$ was found in this organ at various times after ingestion (Table 8). As with plutonium, a small percentage of ${ }^{241}$ Am was observed in other tissues and organs such as cephalothoracic muscle ( 3 to $5 \%$ ) and the cephalothoracic portion of the exoskeleton (12 to $18 \%$ ).

In Palaemon serratus, the ${ }^{237} \mathrm{Pu}$ absorption efficiency could not be accurately determined because too few

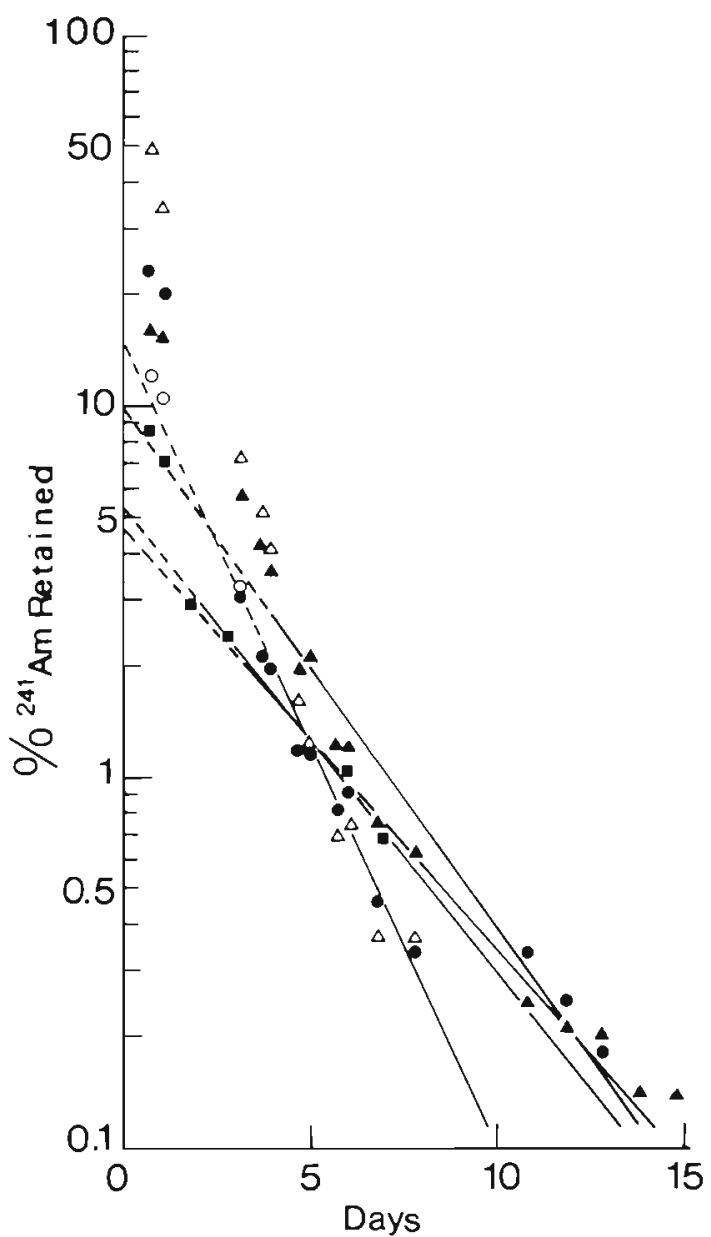

Fig. 4. Palaemon serratus. Elimination of ${ }^{241}$ Am from shrimp $(n=5)$ following ingestion of a single labelled meal. Each symbol represents the residual percentage of ${ }^{241} \mathrm{Am}$ in a single individual. One individual (c) died after $76 \mathrm{~h}$ and therefore was not included in the loss analysis

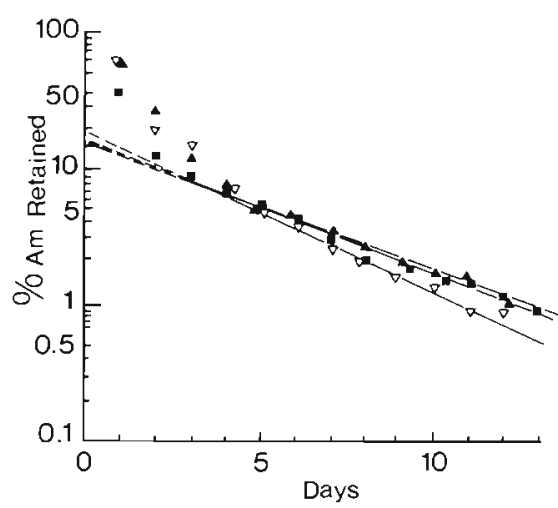

Fig. 5. Pachygrapsus marmoratus. Elimination of ${ }^{241} \mathrm{Am}$ from crabs $(n=6)$ at different stages of the intermoult cycle after single ingestion of labelled mussel. Mean residual percentage of ${ }^{241} \mathrm{Am}$ in 2 crabs at Stage A ( $)$, Stage $C_{2}(\boldsymbol{\wedge})$ and Stage $C_{3}$ to $\mathrm{D}(\because)$ 

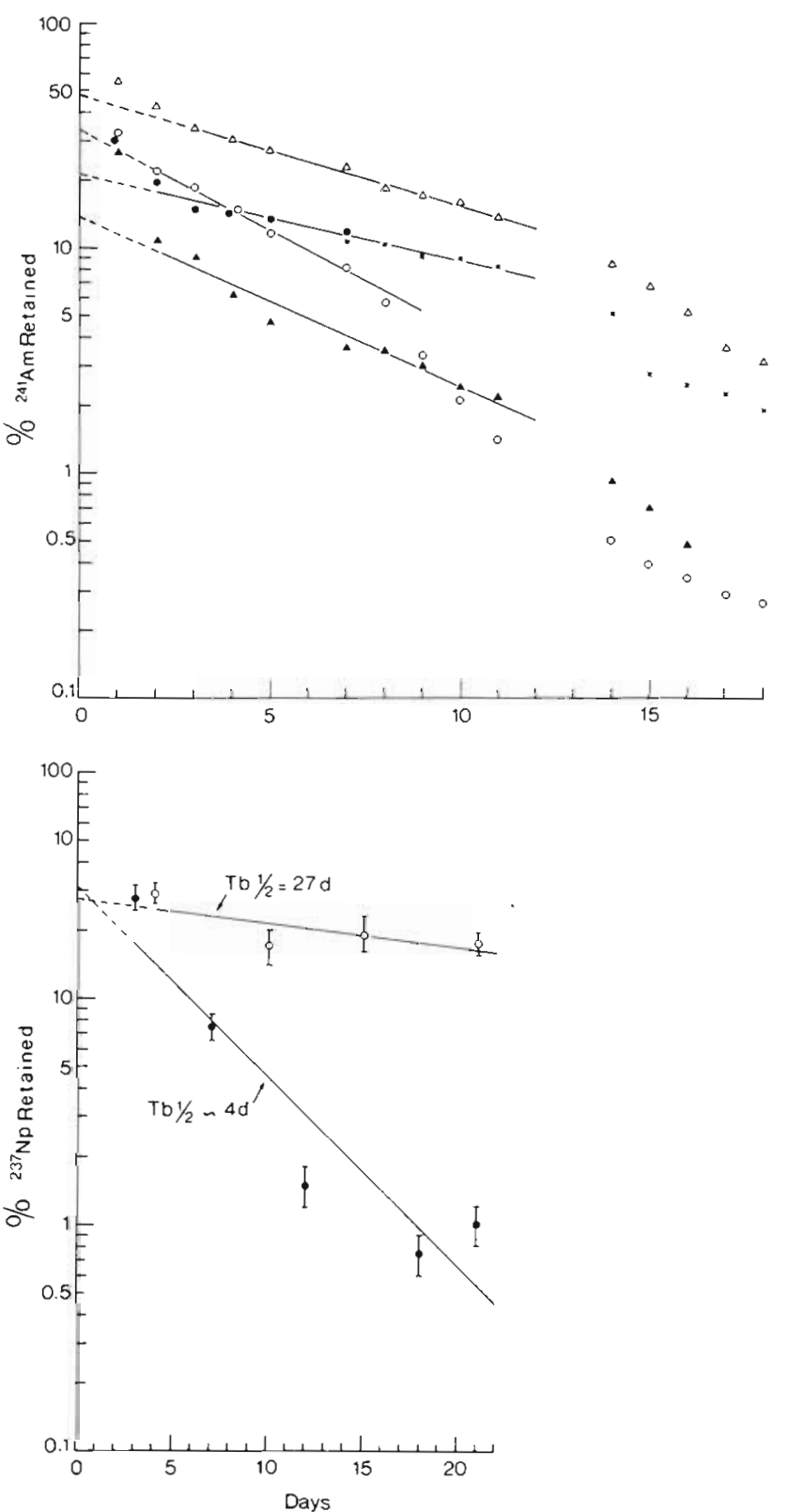

Fig. 6. Carcinus maenas. Eliminatıon of ${ }^{241} \mathrm{Am}$ and ${ }^{27} \mathrm{~Np}$ after ingestion of a single labelled meal. Am: Residual percentage in 2 males $(\bullet 4), 2$ temales (, I and one of the male crabs after moulting $(x)$. Np: Residual percentage in males fed labelled Nereis ( ) ( \pm 1 SD counting error) and in females fed labelled Mytilus $(\bullet)( \pm 1$ SD counting error $)$

specimens remained alive for a sufficiently long time to make replicate loss measurements. However, ingested plutonium appeared to be eliminated from $P$. serratus more rapidly $\left(T_{b^{i}}=c a 2 d\right)$ than from the smaller Lysmata seticaudata, as was the case for ${ }^{241} \mathrm{Am}$ (Table 5). At the end of the elimination experiment (Fig. 4), the distribution of the absorbed ${ }^{241} \mathrm{Am}$ was identical to that observed in L. seticaudata: 50 to $70 \%$ in the hepatopan- creas, 4 to $7 \%$ in the muscle and 18 to $32 \%$ in the cephalothoracic exoskeleton.

Pachygrapsus marmoratus absorbed 16 to $19 \%$ of the ${ }^{241} \mathrm{Am}$ ingested and absorption did not vary substantially with the stage of the moult cycle (Fig. 5). Dissection of crabs 13 d after ingestion of labelled mussel showed that ${ }^{241} \mathrm{Am}$ essentially localized in the hepatopancreas (51 to $61 \%$ ). Different amounts of the radionuclide were observed in other tissues, e.g. stomach and gut ( 2 to $4 \%$ ), gills ( 1 to $6 \%$ ) and exoskeleton ( 13 to $28 \%$ ).

In an earlier study Fowler \& Guary (1977) observed that ${ }^{237} \mathrm{Pu}$ absorption efficiencies for Carcinus maenas varied between 20 and $60 \%$ and that the absorbed fraction turned over with a half-time of 3 to $7 \mathrm{~d}$. The average ${ }^{237} \mathrm{Pu}$ absorption efficiency for C. maenas during the present experiments was $33 \%$ (Table 5). ${ }^{237} \mathrm{Pu}$ was eliminated with an average half-time of $5 \mathrm{~d}$. During the first 2 to $4 \mathrm{~d}$, about $90 \%$ of the eliminated plutonium was egested. After this period, the fraction of total ${ }^{237} \mathrm{Pu}$ egested decreased from 90 to about $40 \%$. Of the absorbed ${ }^{237} \mathrm{Pu}, 45$ to $90 \%$ was fixed in the hepatopancreas (Table 9), $5 \%$ in the muscle, 16 to $44 \%$ in the exoskeleton and 7 to $11 \%$ in the gills, the latter tissue being a possible excretion route for the radionuclide. The ${ }^{237} \mathrm{Pu}$ concentration in the hepatopancreas (dpm $\left.\mathrm{g}^{-1}\right\}$ after $21 \mathrm{~d}$ of elimination always remained higher than in other organs.

The average ${ }^{241} \mathrm{Am}$ absorption efficiency in Carcinus maenas ( $29 \%$ ) was similar to that of plutonium, and the mean half-time of the slow release component ( $5 \mathrm{~d}$ ) was identical (Table 5; Fig. 6). In reality these 2 parameters vary between 14 to $48 \%$ and 3 to $8 \mathrm{~d}$, respectively. One male, which moulted between the 6th and 7 th day of elimination, had ingested the labelled ration at the end of the intermoult cycle which is several months in this species. The moult of this individual contained $9.2 \%$ of the whole body radioactivity content before moulting; about $8.9 \%$ in the cast shell and $0.3 \%$ in the gill fraction. The moult was leached in $0.1 \mathrm{~N} \mathrm{HCl}$ for $120 \mathrm{~h}$ to measure the desorption rate of surficial ${ }^{241} \mathrm{Am}$. After $1 \mathrm{~h}$, the cast exoskeleton had lost only $7.5 \%$ of its radioactive content. After $20 \mathrm{~h}$, ca $15 \%$ was leached and after $120 \mathrm{~h}$, $35 \%$. The elimination of ${ }^{21} \mathrm{Am}$ from the carapace of $C$. maenas by acid leaching was much slower than has been reported for ${ }^{237} \mathrm{Pu}$ loss from exuviae of the shrimp Lysmata seticaudata (ca $50 \%$ lost in 1 h) after accumulation of the radionuclide from seawater (Fowler et al. 1975). These results suggest that ${ }^{241} \mathrm{Am}$ is tightly bound to certain components of the exoskeleton of C. maenas particularly when the radionuclide is transported internally following ingestion.

Three shore crabs were dissected $18 \mathrm{~d}$ after having ingested food labelled with ${ }^{241} \mathrm{Am}$ and the majority of the whole body ${ }^{241} \mathrm{Am}(62$ to $86 \%$ ) was present in the hepatopancreas with smaller amounts in other tissues 
Table 5. Comparative data on averaged absorption efficiencies (e), whole body half-times for loss from the rapid release component $\left(\mathrm{T}_{\mathrm{b} / 2 / 2}\right)$ and the percent retention of transuranic nuclides in the digestive gland (hepatopancreas) ca 2 wk after a single feeding in decapod crustaceans of increasing size

\begin{tabular}{|c|c|c|c|c|c|c|c|c|c|c|}
\hline \multirow[t]{2}{*}{ Species } & \multirow{2}{*}{$\begin{array}{c}\% \\
100 \times \text { dig. } \\
\text { gland wt whole } \\
\text { body wt }\end{array}$} & \multicolumn{3}{|c|}{${ }^{237} \mathrm{Pu}$} & \multicolumn{3}{|c|}{${ }^{24 i} \mathrm{Am}$} & \multicolumn{3}{|c|}{${ }^{237} \mathrm{~Np}$} \\
\hline & & $\begin{array}{c}\mathrm{e} \\
(\%)\end{array}$ & $\begin{array}{l}T_{b 1 / 2} \\
\text { (d) }\end{array}$ & $\begin{array}{l}\% \text { Ret. } \\
\text { in dig. } \\
\text { gland" }\end{array}$ & $\begin{array}{c}\mathrm{e} \\
(\%)\end{array}$ & $\begin{array}{c}T_{b 1 / 2} \\
\text { (d) }\end{array}$ & $\begin{array}{l}\% \text { Ret. } \\
\text { in dig. } \\
\text { gland }\end{array}$ & $\begin{array}{c}\mathrm{e} \\
(\%)\end{array}$ & $\begin{array}{c}T_{b 1 / 2} \\
\text { (d) }\end{array}$ & $\begin{array}{l}\% \text { Ret. } \\
\text { in dig. } \\
\text { gland }\end{array}$ \\
\hline Lysmata seticaudata & 5 & 10 & 4 & 1.5 & 10 & 8 & 2 & - & - & - \\
\hline Palameon serratus & 4 & - & (2) & 0.2 & 8 & 2 & 0.1 & - & - & - \\
\hline Pachygrapsus marmoratus & 6 & - & - & - & 18 & 3 & 1 & - & - & - \\
\hline Carcinus maenas & 8 & 33 & 5 & 5 & 29 & 5 & 4.5 & 30 & $4-27$ & $2-8$ \\
\hline Cancer pagurus & 8 & $(30-40)$ & $(20)$ & $(18)$ & $(10-20)$ & $(20)$ & $(5-9)$ & - & - & - \\
\hline
\end{tabular}

Table 6. Lysmata seticaudata. Concentration and distribution of ${ }^{237} \mathrm{Pu}$ in tissues as a function of time following ingestion of a single labelled ration

\begin{tabular}{|c|c|c|c|c|c|c|c|}
\hline \multirow[t]{2}{*}{ Tissue } & \multirow[t]{2}{*}{$\begin{array}{l}\% \text { Total } \\
\text { wt }\end{array}$} & \multicolumn{2}{|c|}{$\begin{array}{l}\text { Individual no. } 1 \\
{\text { (Day } 3: 5.1 \%)^{\text {d }}}^{\text {Day }}\end{array}$} & \multicolumn{2}{|c|}{$\begin{array}{l}\text { Individual no. } 2^{b} \\
\text { (Day 6: } 2.1 \% \text { ) }\end{array}$} & \multicolumn{2}{|c|}{$\begin{array}{c}\text { Ind. nos. } 3^{b}, 4,5,6^{b} \\
\text { (Day } 13: 5.1 ; 0.2 ; 0.5 ; 0.6 \%)\end{array}$} \\
\hline & & $\begin{array}{l}10^{3} \mathrm{dpm} \\
\mathrm{g}^{-1}\end{array}$ & $\begin{array}{c}\% \text { Total } \\
\text { body burden }\end{array}$ & $\begin{array}{l}10^{3} \mathrm{dpm} \\
\mathrm{g}^{-1}\end{array}$ & $\begin{array}{c}\% \text { Total } \\
\text { body burden }\end{array}$ & $\begin{array}{c}10^{3} \mathrm{dpm} \\
\mathrm{g}^{-1}\end{array}$ & $\begin{array}{l}\% \text { Total body } \\
\text { burden }\end{array}$ \\
\hline Hepatopancreas & 5.2 & 46 & 65.6 & 20 & 54.0 & 45 & 90.4 \\
\hline Stomach and gut & 1.6 & 47 & 11.4 & 25 & 39.5 & 10 & 3.5 \\
\hline Cephalothoracic muscle & 14.3 & 2 & 7.3 & 0.2 & 1.4 & 0.2 & 1.1 \\
\hline Abdominal muscle & 32.7 & nd & - & nd & - & 0.02 & 0.4 \\
\hline Gonads & $0.6-2.4$ & abs & - & nd & - & 2 & 0.6 \\
\hline Gills & 1.9 & 4 & 2.4 & nd & - & nd & - \\
\hline Cephalothoracic exoskeleton & 29.1 & 2.5 & 13.3 & 0.3 & 5.1 & 0.3 & 3.3 \\
\hline Abdominal exoskeleton & 14.2 & nd & - & nd & - & 0.1 & 0.7 \\
\hline \multicolumn{8}{|c|}{$\begin{array}{l}\text { "Numbers in parentheses indicate the day of dissection and percentage of residual radioactivity with respect to ingested } \\
\text { radioactivity } \\
\text { 'Individuals that moulted once } \\
\text { nd: not detected } \\
\text { abs: absent }\end{array}$} \\
\hline
\end{tabular}

Table 7. Lysmata seticaudata. Percentage of ${ }^{24 l} \mathrm{Am}$ in the shrimp and its first moult during the period of elimination following a single labelled feeding

\begin{tabular}{|cccc|}
\hline $\begin{array}{c}\text { Ind. } \\
\text { no. }\end{array}$ & $\begin{array}{c}\text { Time of } \\
\text { moulting } \\
\text { (d) }\end{array}$ & $\begin{array}{c}\text { Percentage } \\
\text { retention of } \\
{ }^{241} \mathrm{Am} \\
\text { in shrimp }\end{array}$ & $\begin{array}{c}\text { Percentage of shrimp } \\
{ }^{241} \text { Am content } \\
\text { (before moulting) } \\
\text { retained in the exuviae }\end{array}$ \\
\hline 1 & 3 & 14.9 & 50 \\
2 & 4 & 2.2 & 18 \\
3 & 12 & 15.2 & 8 \\
4 & 13 & 0.85 & 0 \\
5 & 15 & 0.5 & 0 \\
6 & 15 & 0.15 & 0 \\
7 & 18 & 1.9 & 0 \\
a Number of days after ingestion of labelled meal
\end{tabular}

(Table 10). The exoskeleton of the male crab that moulted on Day 6 still contained about $9 \%$ of the total radioactivity, i.e. the same proportion that was found in its cast exuviae

Absorption efficiency of ${ }^{237} \mathrm{~Np}$ by Carcinus maenas was also measured and found to range between 28 and $31 \%$. The biological half-time of the slow release component varied between 4 and $27 \mathrm{~d}$ and apparently depended upon the type of food ingested (Fig. 6). During excretion the elimination of neptunium by egestion decreased in importance (from between 80 and $90 \%$ to $30 \%$ ) relative to the soluble excretion route as found for ${ }^{237} \mathrm{Pu}$ and ${ }^{241} \mathrm{Am}$. Nevertheless, ${ }^{237} \mathrm{~Np}$ appears more translocatable than either plutonium or americium

Although ${ }^{237} \mathrm{~Np}$ is readily accumulated (37 to $45 \%$ ) in the hepatopancreas of male crabs, a relatively high 
Table 8. Lysmata seticaudata. Distribution of ${ }^{241} \mathrm{Am}$ in tissues of shrimp as a function of time after ingestion of a single labelled meal

\begin{tabular}{|c|c|c|c|c|c|c|c|}
\hline \multirow[t]{2}{*}{ Tissue } & \multirow{2}{*}{$\begin{array}{l}\text { \% Whole } \\
\text { body wt }\end{array}$} & \multicolumn{6}{|c|}{ Time $(d)$} \\
\hline & & 4 & 4 & 5 & 10 & $24^{\mathrm{a}}$ & $30^{\mathrm{b}}$ \\
\hline Hepatopancreas & 5.0 & 65.8 & 67.2 & 73.9 & 72.6 & 100 & 100 \\
\hline Stomach and gut & 1.0 & 8.9 & 20.3 & 3.3 & 4.7 & nd & nd \\
\hline Cephalothoracic muscle & 19.8 & 3.5 & nd & 5.5 & 4.8 & nd & nd \\
\hline Abdominal muscle & 33.4 & 1.6 & nd & 0.1 & nd & nd & nd \\
\hline Gills & 1.8 & ) 178 & & 3169 & 6.0 & nd & nd \\
\hline Cephalothoracic exoskeleton & 27.3 & \} 17.8 & \} 12.5 & \} 16.9 & 11.9 & nd & nd \\
\hline Abdominal exoskeleton & 11.7 & 2.4 & nd & 0.3 & nd & nd & nd \\
\hline \multicolumn{2}{|c|}{$\begin{array}{l}\text { Whole body percentage retention at time } \\
\text { of dissection }\end{array}$} & 25.9 & 9.7 & $\approx 100$ & 0.8 & 2.3 & 2.8 \\
\hline \multicolumn{8}{|c|}{$\begin{array}{l}\text { andividual that moulted twice during the experiment } \\
\text { 'Individual that moulted once during the experiment } \\
\text { nd: not detected }\end{array}$} \\
\hline
\end{tabular}

proportion of the radionuclide is found in the exoskeleton (37 to $52 \%$ ) and gills ( 5 to $11 \%$ ). Despite the relatively low ${ }^{237} \mathrm{~Np}$ concentration in the exoskeleton, this tissue represents about $63 \%$ of the crab's weight, and this partly explains the high percentage of whole body neptunium observed in the exoskeleton (Table 11). In the same experiments, the hepatopancreas of female crabs (not shown) also fixed a high proportion of ${ }^{237} \mathrm{~Np}(60$ to $70 \%)$, slightly higher than that observed in the hepatopancreas of the male crabs
Although it was not possible to precisely measure ${ }^{237} \mathrm{Pu}$ and ${ }^{241} \mathrm{Am}$ absorption efficiencies for the large edible crab Cancer pagurus, we estimated by indirect means that efficiencies were high and at least equal to those measured in Carcinus maenas. The amount of ${ }^{237} \mathrm{Pu}$ found in the tissues of $\mathrm{C}$. pagurus ca $3 \mathrm{wk}$ after ingestion of radioactive food was still high, about 18 to $41 \%$ of the amount ingested (Table 12). As in other crustaceans, the majority of the $\mathrm{Pu}$ was located in the hepatopancreas ( 76 to $85 \%$ ) which only represents 8 to

Table 9. Carcinus maenas. Concentration and percentage of the ${ }^{237} \mathrm{Pu}$ in tissues of females as a function of time after ingestion of a single labelled meal

\begin{tabular}{|c|c|c|c|c|c|c|}
\hline \multirow[t]{2}{*}{ Tissue } & & \multicolumn{5}{|c|}{ Time (d) } \\
\hline & & 8 & 14 & 14 & $21^{\text {d }}$ & $21^{\text {क }}$ \\
\hline Hepatopancreas & $\mathrm{dpm} \mathrm{g}^{-1}$ & $\begin{array}{c}475 \pm 25 \\
85.4\end{array}$ & $\begin{array}{c}475 \pm 25 \\
91.2\end{array}$ & $\begin{array}{c}460 \pm 25 \\
89.2\end{array}$ & $\begin{array}{c}175 \pm 10 \\
54.4\end{array}$ & $\begin{array}{c}175 \pm 10 \\
44.9\end{array}$ \\
\hline Stomach and gut & $\operatorname{dpm} \mathrm{g}^{-1}$ & $\begin{array}{c}n d \\
-\end{array}$ & $\begin{array}{l}\text { nd } \\
-\end{array}$ & $\begin{array}{c}\text { nd } \\
-\end{array}$ & $\begin{array}{c}\text { nd } \\
-\end{array}$ & $\begin{array}{l}\text { nd } \\
-\end{array}$ \\
\hline Hemolymph & $\operatorname{dpm} g^{-1}$ & $\begin{array}{c}\text { nd } \\
-\end{array}$ & nd & $\begin{array}{c}\text { nd } \\
-\end{array}$ & $\begin{array}{c}\text { nd } \\
-\end{array}$ & nd \\
\hline Muscle & $\underset{\%}{\mathrm{dpm}} \mathrm{g}^{-1}$ & $\begin{array}{l}\text { nd } \\
-\end{array}$ & $\begin{array}{l}\text { nd } \\
-\end{array}$ & $\begin{array}{l}\text { nd } \\
-\end{array}$ & $\begin{array}{l}\text { nd } \\
-\end{array}$ & $\begin{array}{c}15 \pm 5 \\
5.0\end{array}$ \\
\hline Gills & $\operatorname{dpm} \mathrm{g}^{-1}$ & nd & nd & nd & $\begin{array}{c}125 \pm 50 \\
11.2\end{array}$ & $\begin{array}{c}75 \pm 25 \\
6.6\end{array}$ \\
\hline Epıdermis & $\underset{\%}{\mathrm{dpm}} \mathrm{g}^{-1}$ & $\begin{array}{l}\text { nd } \\
-\end{array}$ & $\begin{array}{c}\text { nd } \\
-\end{array}$ & nd & $\begin{array}{c}310 \pm 10 \\
18.4\end{array}$ & nd \\
\hline Exoskeleton & $\operatorname{dpm} g^{1}$ & $\begin{array}{c}20 \pm 5 \\
14.6\end{array}$ & $\begin{array}{c}10 \pm 2 \\
8.8\end{array}$ & $\begin{array}{c}10 \pm 4 \\
10.8\end{array}$ & $\begin{array}{c}10 \pm 4 \\
16.0\end{array}$ & $\begin{array}{c}40 \pm 2 \\
43.5\end{array}$ \\
\hline \multicolumn{2}{|c|}{$\begin{array}{l}\text { Whole body percentage retention at } \\
\text { time of dissection }\end{array}$} & 3.5 & 3.9 & 6.7 & 0.5 & 1.7 \\
\hline \multicolumn{7}{|c|}{$\begin{array}{l}\text { "Individuals received worms which were exposed to radiotracer originally in (V+VI) oxidation state (see comments in } \\
\text { 'Materials and methods') } \\
\text { nd: not detected }\end{array}$} \\
\hline
\end{tabular}


Table 10. Carcinus maenas. Concentration and distribution of ${ }^{241} \mathrm{Am}$ in tissues $18 \mathrm{~d}$ after a single labelled meal

\begin{tabular}{|c|c|c|c|c|c|c|c|}
\hline \multirow[t]{2}{*}{ Tissue } & \multirow{2}{*}{$\begin{array}{l}1 \% \text { Whole } \\
\text { body wt }\end{array}$} & \multicolumn{2}{|c|}{ [nd. no. $1^{\mathrm{d}}(\delta .1 .9 \%)$} & \multicolumn{2}{|c|}{ Ind no. $2^{\mathrm{d}}(9 \cdot 0.3 \%)$} & \multicolumn{2}{|c|}{ Ind no. $3^{\mathrm{d}}(9: 3.1 \%)$} \\
\hline & & $d p m g^{-1}$ & $\begin{array}{l}\% \text { Body } \\
\text { burden }\end{array}$ & $\mathrm{dpm} \mathrm{g}^{-1}$ & $\begin{array}{l}\% \text { Body } \\
\text { burden }\end{array}$ & $\mathrm{dpm} \mathrm{g}^{-1}$ & $\begin{array}{l}\% \text { Body } \\
\text { burden }\end{array}$ \\
\hline Hepatopancreas & 8.8 & 1540 & 86.4 & 290 & 62.4 & 960 & 77.7 \\
\hline Stomach & 1.2 & 70 & 0.5 & nd & - & nd & - \\
\hline Gut & 0.2 & nd & - & nd & - & nd & - \\
\hline Gonads & $(3-5)$ & nd & - & 105 & 7.5 & 55 & 2.8 \\
\hline Hemolymph & 4.5 & nd & - & nd & - & nd & - \\
\hline Muscle & 12.6 & 30 & 3.0 & 15 & 3.7 & 25 & 2.8 \\
\hline Gills & 5.0 & 40 & 1.4 & nd & - & 50 & 2.8 \\
\hline Epidermis & 1.5 & nd & - & nd & - & 125 & 2.2 \\
\hline Exoskeleton & 63.2 & 20 & 8.7 & 15 & 22.6 & 20 & 11.7 \\
\hline \multicolumn{8}{|c|}{$\begin{array}{l}\text { "Ind. no. } 1(22 \mathrm{~g}) \text { moulted during the night between Days } 6 \text { and } 7 \text { of elimination. Ind. nos. } 2 \text { and } 3 \text { weighed } 14 \text { and } 19 \mathrm{~g} \text {, } \\
\text { respectively. The information in parentheses indicates the sex of the crab and percentage of residual radioactivity after } 18 \mathrm{~d} \\
\text { elimination with respect to initial radioactivity }\left(1.7 \times 10^{5} \mathrm{dpm}, 1.8 \times 10^{5} \mathrm{dpm} \text { and } 4.3 \times 10^{4} \mathrm{dpm} \text { respectively) }\right. \\
\text { nd: not detected }\end{array}$} \\
\hline
\end{tabular}

$10 \%$ of the total weight of the crab. The concentration of ${ }^{237} \mathrm{Pu}$ in this organ was an order of magnitude greater than the concentration in other tissues. Using these data the biological half-time of the slow release component was estimated to be about $20 \mathrm{~d}$ and the absorption efficiency ca 30 to $40 \%$ (not shown). The proportion of ${ }^{237} \mathrm{Pu}$ egested decreased greatly after several days as soluble radionuclide excretion became predominant during the slow elimination phase. Retention of ${ }^{241} \mathrm{Am}$ in the tissues of $C$. pagurus was only 2 to $4 \% 1$ mo after the labelled food was ingested. Assuming that the halftime of the slow release component for ${ }^{241} \mathrm{Am}$ in $\mathrm{C}$. pagurus was almost identical to that of ${ }^{237} \mathrm{Pu}(20 \mathrm{~d})$, we estimate that ${ }^{241} \mathrm{Am}$ absorption is lower than ${ }^{237} \mathrm{Pu}$ absorption and is on the order of 10 to $20 \%$. Likewise, ${ }^{241} \mathrm{Am}$ is strongly fixed in the crab hepatopancreas $(60$ to $70 \%$ ), but appears more evenly distributed among the other tissues than is ${ }^{237} \mathrm{Pu}$ (Table 13). Substantial

Table 11. Carcinus maenas. Concentration and distribution of ${ }^{237} \mathrm{~Np}$ in tissues of males as a function of time after ingestion of a single labelled meal

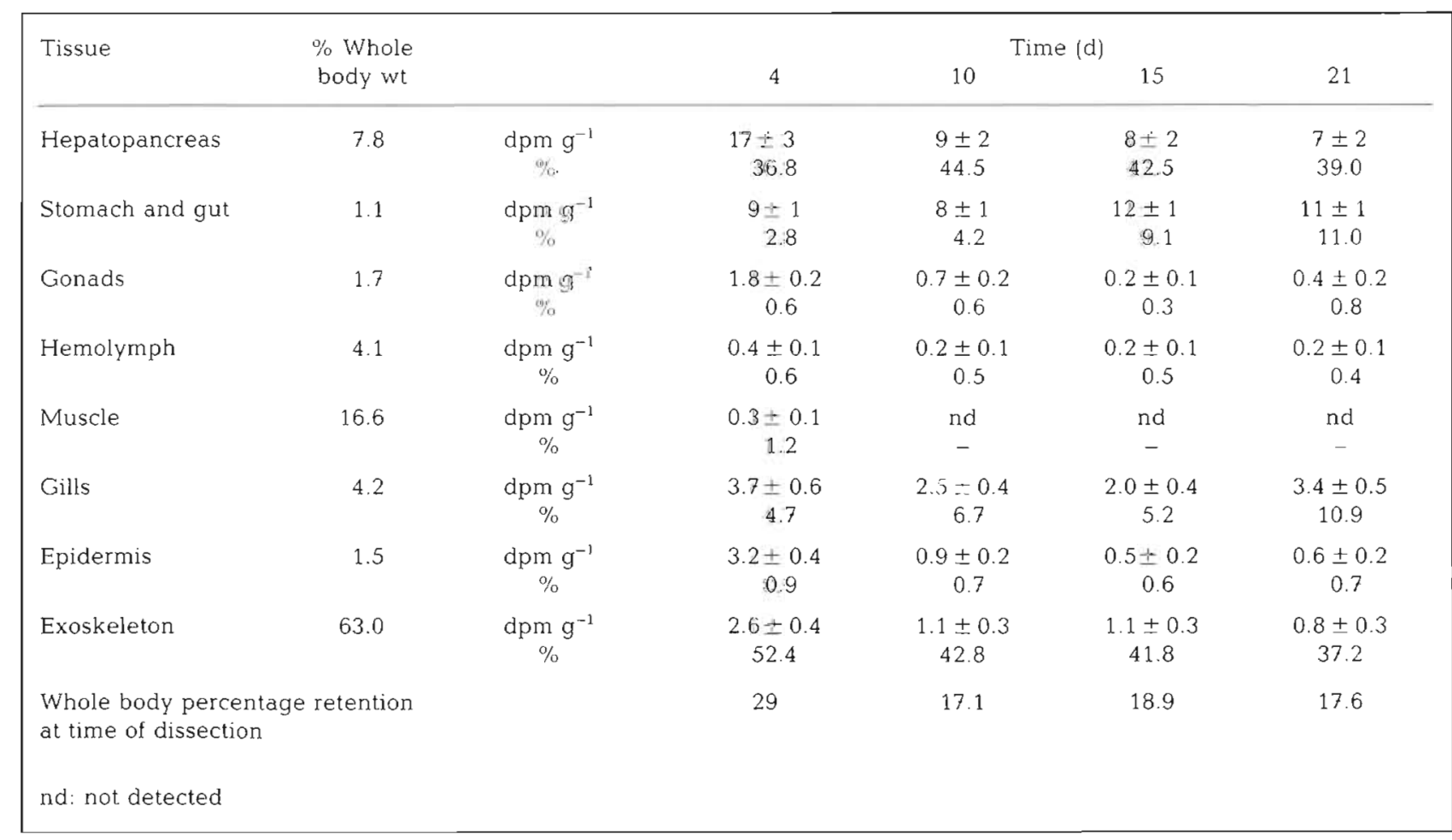


Table 12. Cancer pagurus. Temporal changes in concentration $\left(\times 10^{3}\right)$ and distribution of ${ }^{237} \mathrm{Pu}$ in tissues after ingestion of a single labelled meal

\begin{tabular}{|c|c|c|c|c|c|}
\hline \multirow[t]{2}{*}{ Tissue } & \multirow{2}{*}{\multicolumn{2}{|c|}{$\begin{array}{c}\% \\
\text { Whole } \\
\text { body wt }\end{array}$}} & \multicolumn{3}{|c|}{ Time (d) } \\
\hline & & & 6 & 17 & 20 \\
\hline Hepatopancreas & 9.7 & $\mathrm{dpm}_{\%} \mathrm{~g}^{-1}$ & $\begin{array}{l}16 \\
75.8\end{array}$ & $\begin{array}{r}0.7 \\
84.6\end{array}$ & $\begin{array}{r}0.5 \\
85.2\end{array}$ \\
\hline Stomach & 0.5 & $\underset{\%}{\mathrm{dpm}} \mathrm{g}^{-1}$ & $\begin{array}{l}3 \\
1.0\end{array}$ & $\begin{array}{l}0.03 \\
0.3\end{array}$ & $\begin{array}{l}0.05 \\
0.3\end{array}$ \\
\hline Gut & 0.2 & $\underset{\%}{\operatorname{dpm}} \mathrm{g}^{-1}$ & $\begin{array}{l}0.7 \\
0.1\end{array}$ & $\begin{array}{c}\text { nd } \\
-\end{array}$ & $\begin{array}{c}\text { nd } \\
-\end{array}$ \\
\hline Gonads & $(1-3)$ & $\operatorname{dpm} g^{-1}$ & $\begin{array}{l}0.15 \\
0.3\end{array}$ & $\begin{array}{l}\text { nd } \\
0.2\end{array}$ & $\begin{array}{l}\text { nd } \\
-\end{array}$ \\
\hline Hemolymph & 11.2 & $\mathrm{dpm}_{\%} \mathrm{~g}^{-1}$ & $\begin{array}{l}0.2 \\
1.2\end{array}$ & $\begin{array}{l}\text { nd } \\
1.0\end{array}$ & $\begin{array}{c}\text { nd } \\
-\end{array}$ \\
\hline Muscle & 20.2 & $\underset{\%}{\operatorname{dpm}} \mathrm{g}^{-1}$ & $\begin{array}{l}0.08 \\
1.5\end{array}$ & $\begin{array}{l}\text { nd } \\
0.5\end{array}$ & $\begin{array}{l}\text { nd } \\
1.0\end{array}$ \\
\hline Gills & 2.8 & $\underset{\%}{\operatorname{dpm}} \mathrm{g}^{-1}$ & $\begin{array}{l}2.5 \\
4.0\end{array}$ & $\begin{array}{l}0.04 \\
2.4\end{array}$ & $\begin{array}{l}0.2 \\
6.2\end{array}$ \\
\hline Epidermis & 2.8 & $\mathrm{dpm}_{\%} \mathrm{~g}^{-1}$ & $\begin{array}{l}0.8 \\
1.4\end{array}$ & $\begin{array}{l}0.01 \\
0.7\end{array}$ & $\begin{array}{l}0.03 \\
1.2\end{array}$ \\
\hline Exoskeleton & 50.6 & $\mathrm{dpm} \mathrm{g}_{\%}^{-1}$ & $\begin{array}{r}0.3 \\
14.7\end{array}$ & $\begin{array}{l}0.01 \\
10.3\end{array}$ & $\begin{array}{l}0.01 \\
6.1\end{array}$ \\
\hline $\begin{array}{l}\text { Whole body perc } \\
\text { retention at time } \\
\text { dissection }\end{array}$ & $\begin{array}{l}\text { rentage } \\
\text { of }\end{array}$ & & 27 & 18 & 41 \\
\hline nd: not delected & & & & & \\
\hline
\end{tabular}

amounts of americium were also observed in the ovaries ( 6 to $10 \%$ ), muscle ( 4 to $5 \%$ ), gill ( 2 to $3 \%$ ) and exoskeleton (12 to $21 \%$ ). Muscle was separated into 2 parts: the pereiopod muscle (14\% of the total weight) and the cephalothoracic muscle $16 \%$ of the total weight). Apparently cephalothoracic muscle concentrated twice as much ${ }^{241} \mathrm{Am}$ as pereiopod muscle. The exoskeleton was also divided into 3 segments: the mouth parts ( $4 \%$ of whole body weight), the pereiopods ( $31 \%$ of the total weight) and the carapace $(13.5 \%$ of the total weight). The mouth parts portion of the exoskeleton concentrated 3 times as much ${ }^{241} \mathrm{Am}$ as the carapace and 7 times more than the pereiopods. The mouth parts were probably externally contaminated to some degree at the time the labelled food was masticated; however, ${ }^{241} \mathrm{Am}$ transfer from the hepatopancreas to other tissues and organs such as ovaries, muscle and most portions of the exoskeleton certainly predominates.

\section{Absorption and transfer of ${ }^{241} \mathrm{Am}$ in Carcinus maenas after multiple feedings of labelled meals}

The average ${ }^{241} \mathrm{Am}$ ingestion efficiency was about $65 \%( \pm 15 \%)$. The crabs thus ingested on average 2.5 to $2.9 \times 10^{5} \mathrm{dpm}$ at each meal. The ${ }^{241} \mathrm{Am}$ food transfer efficiency between labelled mussels and whole shore crabs was low, ranging from 2.2 to $6.2 \%$. On the other hand, the ${ }^{241} \mathrm{Am}$ transfer efficiency for hepatopancreas was very high, ranging between 25 and $70 \%$ with an average value of $45 \%$. This confirms the previous data from single meal experiments, which indicated a high americium absorption efficiency (ca $30 \%$ ) in Carcinus maenas.

From the data of the previous experiment, we estimated that $7 \mathrm{~d}$ post-ingestion of labelled food, the assimilated portion of ingested ${ }^{241} \mathrm{Am}$ was slowly eliminated via normal excretory processes. The average residual percentage of ${ }^{241} \mathrm{Am} 1 \mathrm{wk}$ after the first

Table 13. Cancer pagurus. Concentration and distribution of ${ }^{2+1} \mathrm{Am}$ in tissues of females $30 \mathrm{~d}$ after a labelled meal (5 and 6 shrimps ingested in $48 \mathrm{~h}$ )

\begin{tabular}{|c|c|c|c|c|c|}
\hline \multirow[t]{2}{*}{ Tissue } & \multirow[t]{2}{*}{$\%$ Whole body wt } & \multicolumn{2}{|c|}{ Ind no. $1\left(3.8^{\circ},\right)^{n}$} & \multicolumn{2}{|c|}{ Ind. no. $2(2.3 \%)^{a}$} \\
\hline & & $10^{3} \mathrm{dpm} \mathrm{g}$ & $\begin{array}{c}\text { "" Total } \\
\text { body burden }\end{array}$ & $10^{3} \mathrm{dpm} \mathrm{g}^{-1}$ & $\begin{array}{c}\% \text { Total } \\
\text { body burden }\end{array}$ \\
\hline Hepatopancreas & 6.3 & 1.3 & 69.8 & 1.1 & 63.9 \\
\hline Stomach & 0.7 & 0.2 & 0.9 & 0.07 & 0.7 \\
\hline Gut & 0.3 & 0.05 & 0.1 & 0.03 & 0.1 \\
\hline Ovaries & $3-6$ & 0.2 & 10.0 & 0.2 & 5.7 \\
\hline Hemolymph & 12.8 & nd & - & nd & - \\
\hline Muscle & 20.2 & 0.04 & 5.0 & 0.02 & 4.2 \\
\hline Gills & 3.1 & 0.07 & 1.6 & 0.09 & 2.8 \\
\hline Epidermis & 3.5 & 0.04 & 0.8 & 0.04 & 16 \\
\hline Exoskeleton & 48.5 & 0.04 & 11.8 & 0.04 & 21.0 \\
\hline
\end{tabular}




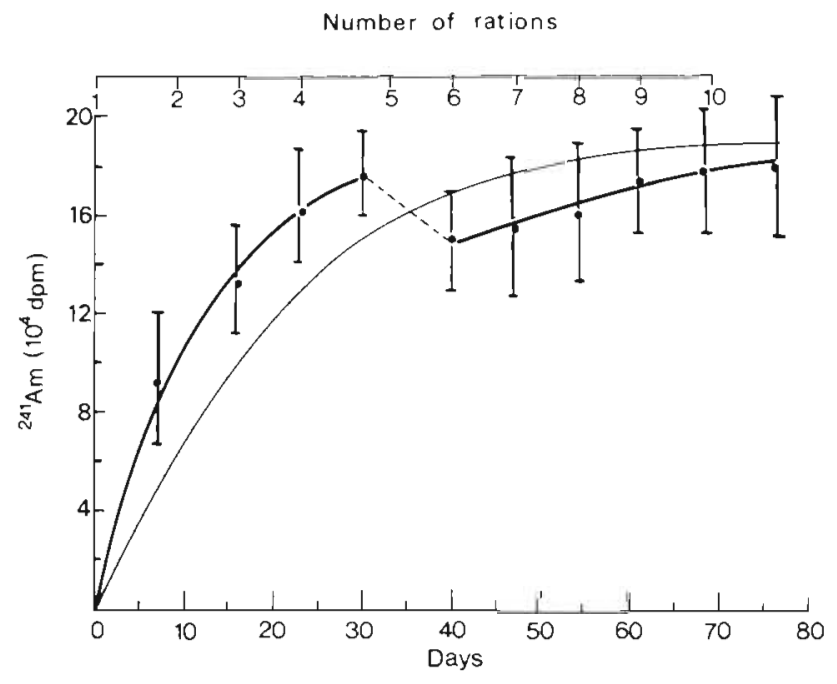

Fig. 7. Carcinus maenas. Accumulation of ${ }^{241} \mathrm{Am}(\mathrm{n}=6) \mathrm{du}-$ ring sequential feeding with labelled mussels. ( $\bullet$ ) Average residual radioactivity in 6 individuals $7 \mathrm{~d}$ after each labelled meal; (-) actual accumulation; (-) theoretical accumulation; (--) period of elimination

radioactive meal was about $36 \%$. This percentage increased slowly during the experiment, and $7 \mathrm{~d}$ after the 10 th and last meal, it approached $45 \%$. Thus more americium was accumulated by Carcinus maenas during the same period than was eliminated. The radioactive body burden of the crabs increased very rapidly for the first $30 \mathrm{~d}$ (Fig. 7), during which time the first 4 contaminated rations were ingested. Between Days 30 and $40,{ }^{241} \mathrm{Am}$ was eliminated faster than it was accumulated. After the 10th and final radioactive meal, it appeared that the crabs' radioactive body burden had almost reached a steady state. At the end of the experi- ment, the average residual ${ }^{241} \mathrm{Am}$ in the crabs $7 \mathrm{~d}$ after the last radioactive meal was $1.8 \times 10^{5} \mathrm{dpm}$, i.e. about 60 to $70 \%$ of the total ${ }^{241} \mathrm{Am}$ available in the labelled rations. Crab weight measurements made at the time of dissection indicated that no measurable growth occurred during the experiment.

The hepatopancreas was the principal absorption site of the ${ }^{241}$ Am accumulated during continued feedings in Carcinus maenas (Table 14). In every case this organ fixed 50 to $70 \%$ of the radionuclide retained by the crab $7 \mathrm{~d}$ after ingestion of the labelled food. The concentrations of ${ }^{241} \mathrm{Am}$ in the hepatopancreas after Day 76 of the experiment ranged from 0.5 to $2.6 \times 10^{5}$ dpm $\mathrm{g}^{-1}$, a level which represented about 15 to $90 \%$ of the ${ }^{241} \mathrm{Am}$ concentration in the ingested soft parts of mussels. Note that the ${ }^{241} \mathrm{Am}$ concentration in the whole crab $\left(9 \times 10^{3} \mathrm{dpm} \mathrm{g}^{-1}\right)$ was an order of magnitude less than the concentration in the hepatopancreas.

Other tissues and organs accumulated small amounts of ${ }^{241} \mathrm{Am}$. Up to $3 \%$ of the total ${ }^{241} \mathrm{Am}$ retained by Carcinus maenas was found in the ovaries. The muscle also fixed more than $2 \%$ of the ${ }^{241} \mathrm{Am}$ retained by the crab, in particular the cephalothoracic muscle. These results strongly support the hypothesis of internal transfer of ${ }^{241} \mathrm{Am}$ from the hepatopancreas to other organs despite low concentrations in the hemolymph (Table 14). Finally, relatively significant ${ }^{241} \mathrm{Am}$ concentrations ( 6 to $12 \times 10^{3} \mathrm{dpm} \mathrm{g}^{-1}$ ) were observed in the gills, epidermis and exoskeleton. The exoskeleton represented more than $60 \%$ of the weight of the crab, and contained on average $20 \%$ of the total americium accumulated.

These experiments have confirmed the role of the hepatopancreas in the retention of ${ }^{241} \mathrm{Am}$ ingested with

Table 14. Carcinus maenas. Changes in concentration and distribution of $4 \mathrm{~m}$ in tissues of females during sequential feedings of labelled mussels. Crabs were dissected $7 \mathrm{~d}$ after the $3 \mathrm{rd}, 5$ th and 10 th radioactive meals

\begin{tabular}{|c|c|c|c|c|c|c|c|}
\hline \multirow[t]{2}{*}{ Tissue } & \multirow[t]{2}{*}{$\begin{array}{l}\% \text { Whole } \\
\text { body wt }\end{array}$} & \multicolumn{2}{|c|}{$\begin{array}{c}\text { Ind. no. } 1.3 \text { meals } \\
\text { GI }=4\end{array}$} & \multicolumn{2}{|c|}{$\begin{array}{c}\text { Ind. no. 10: } 5 \text { meals } \\
\text { GI }=8.5\end{array}$} & \multicolumn{2}{|c|}{$\begin{array}{c}\text { Ind. nos. } 2,4,6,7,8,9: 10 \\
\text { meals } 1<G I<6\end{array}$} \\
\hline & & $10^{3} \mathrm{dpm} \mathrm{g} \mathrm{g}^{-1}$ & $\begin{array}{l}\% \text { Total } \\
\text { body } \\
\text { burden }\end{array}$ & $10^{3} \mathrm{dpm} \mathrm{g^{-1 }}$ & $\begin{array}{l}\% \text { Total } \\
\text { body } \\
\text { burden }\end{array}$ & $10^{3} \mathrm{dpm} \mathrm{g}^{-1}$ & $\begin{array}{c}\% \text { Total } \\
\text { body } \\
\text { burden } \\
(\bar{x} \pm 1 \mathrm{SD})\end{array}$ \\
\hline Hepatopancreas & 7.4 & 46 & 48.4 & 230 & 51.0 & $46-260$ & $70.8 \pm 4.6$ \\
\hline Stomach & 1.3 & 10 & 2.5 & 48 & 3.9 & $2-19$ & $0.8 \pm 0.4$ \\
\hline Gut & 0.2 & 7.5 & 0.4 & 68 & 1.5 & $6.4-25$ & $0.2 \pm 0.05$ \\
\hline Ovaries & $2-10$ & 2 & 1.1 & 4.8 & 3.0 & $3.6-19$ & $2.2 \pm 1.5$ \\
\hline Hemolymph & 5.4 & 0.2 & 0.2 & 3.4 & 1.7 & $0.2-2$ & $0.4 \pm 0.2$ \\
\hline Muscle & 13.3 & 0.6 & 2.3 & 2.9 & 3.5 & $0.8-3$ & $2.1 \pm 0.3$ \\
\hline Gills & 5.2 & 2.9 & 2.9 & 13 & 3.8 & $3.4-12$ & $2.6 \pm 0.6$ \\
\hline Epidermis & 1.7 & 2 & 0.5 & 7.9 & 0.4 & $2-7.5$ & $1.4 \pm 1.0$ \\
\hline Exoskeleton & 61.3 & 4 & 41.7 & 10 & 31.2 & $2-6$ & $19.5 \pm 1.7$ \\
\hline GI: Gonad Index & & & & & & & \\
\hline
\end{tabular}


labelled food. They also demonstrated that the shore crab Carcinus maenas fed continuously with labelled food accumulates increasing amounts of americium until reaching a near equilibrium body burden after about $80 \mathrm{~d}$ and 10 ingested rations. However, under these experimental conditions the concentration of ${ }^{24} \mathrm{Am}$ in the whole crab probably could not exceed that of its prey, in this case, mussels.

\section{DISCUSSION AND CONCLUSION}

\section{Bioaccumulation of ${ }^{237} \mathrm{Pu}$ and ${ }^{241} \mathrm{Am}$ from seawater in Carcinus maenas: role of exoskeleton and gills}

Americium and plutonium appear to be accumulated by decapods more rapidly than neptunium (Guary \& Fowler 1977, 1978). This conclusion is also supported by studies with euphausiid crustaceans which indicate a low bioavailability of $\mathrm{Np}$ relative to the other transuranics (Fowler \& Aston 1982, Aston \& Fowler 1983).

Under the conditions used in the decapod studies, the greatest proportion of ${ }^{237} \mathrm{Pu}^{241} \mathrm{Am}$, and ${ }^{237} \mathrm{~Np}(70$ to $90 \%$; Guary \& Fowler 1977, 1978) is fixed to the exoskeleton mainly because this tissue, accounting for almost half the weight of these crustaceans, constitutes a large surface area for adsorption. Ward (1966) demonstrated that the exoskeleton of the lobster Homarus vulgaris rapidly accumulated ${ }^{239} \mathrm{Pu}$ from seawater and could fix up to $90 \%$ of the plutonium accumulated in $220 \mathrm{~d}$. Likewise, the exoskeleton of the same species contained $84 \%$ of the whole body burden of ${ }^{241} \mathrm{Am}$ following a $14 \mathrm{~d}$ exposure in labelled seawater (Miramand et al. 1989). The majority of the ${ }^{24 !} \mathrm{Am},{ }^{237} \mathrm{Pu}$ and ${ }^{252} \mathrm{Cf}$ (californium) accumulated by the euphausiid Meganyctiphanes norvegica or the shrimp Lysmata seticaudata was fixed in the cast exoskeleton recovered after moulting (Fowler et al. 1975, Aston \& Fowler 1983, Fisher et al. 1983). Guary \& Fowler $(1977,1978)$ also measured high concentrations of ${ }^{237} \mathrm{~Np}$ in the moults of $L$. seticaudata during uptake. These various data demonstrate that transuranic elements $(\mathrm{Np}, \mathrm{Pu}, \mathrm{Am}$, Cf) have in common a very high affinity for the exoskeleton of crustaceans, and that moulting plays a predominant role in regulation of body burdens and transfer of these elements between crustaceans and their environment. The behaviour of transuranic elements is thus comparable to that of various other heavy metals in marine crustaceans (Bryan 1976, Fowler 1982)

Transuranics, notably ${ }^{237} \mathrm{Pu}$ and ${ }^{241} \mathrm{Am}$, also have high affinity for the gills of crustaceans which, despite the low weight fraction they represent, constitute a large surface area for radionuclide exchange with the environment. Gill tissue retained 24 to $30 \%$ of the ${ }^{237} \mathrm{Pu}$ and ${ }^{241} \mathrm{Am}$ accumulated by the crab Carcinus maenas; however, less than $2 \%$ of ${ }^{237} \mathrm{~Np}$ taken up by shrimp and crabs was found in the gills (Guary \& Fowler 1978). Furthermore, gills concentrated about 4 times more of these 2 radionuclides than the exoskeleton of the shore crab. However, this was not the case for the gills of the lobster Homarus vulgaris which, after 220 d of accumulation of ${ }^{239} \mathrm{Pu}$ from seawater, reached nearly the same Pu concentration factor (100) as the exoskeleton (Ward 1966). Crustacean gills, in particular those of brachyurans, constitute a significant site for the absorption and excretion of various elements such as heavy metals (Wright 1978, Bryan 1984). Martin (1975), in his study of Fe in crustaceans, suggested that lobster gills, which have a different structure from those of the brachyuran decapods C. maenas and Cancer irroratus, have no filtering function and, thus, fix much less Fe than crab gills. Similar reasoning may hold for the transuranic elements which are often associated with fine particulate matter. Finally, our experimental results for $C$. maenas showing much greater ${ }^{237} \mathrm{Pu}$ and ${ }^{241} \mathrm{Am}$ uptake by gill than hepatopancreas (Table 3) agree well with the natural distribution of plutonium and americium in tissues of the crab Cancer pagurus contaminated in the environment (Guary et al. 1976, Hetherington et al. 1976). This similarity in relative distribution suggests that, in the natural environment, uptake from water plays a significant role in the bioaccumulation of transuranics by decapods.

In contrast, transuranic elements in seawater are only slightly accumulated by the internal tissues that are never in direct contact with the contaminated seawater. This is especially true for the hemolymph which generally contains less than $0.3 \%$ of the transuranic element accumulated from seawater. With the exception of the epidermis (CF 10 to 40 ) only very low concentrations of ${ }^{237} \mathrm{Pu}$ and ${ }^{241} \mathrm{Am}$ were found in these internal tissues. Neptunium-237 concentrates in a similar manner in decapods (Guary \& Fowler 1978). On the other hand, Homarus vulgaris can fix as much as $5 \%$ of the ${ }^{239} \mathrm{Pu}$ in its hepatopancreas at the end of a much longer exposure time $(220 \mathrm{~d})$ and eventually reaches the same concentration factor as the exoskeleton and gills (Ward 1966).

In summary, transuranic elements are transferred from seawater to internal tissues via the exoskeleton. and gills, but this process occurs relatively slowly and is much slower than for the majority of heavy metals and natural radioelements. For example, metals such as Zn, $\mathrm{Cu}, \mathrm{Fe}, \mathrm{Cd}, \mathrm{Hg}$ and $\mathrm{Pb}$ (Bryan 1976, Wright 1978) and ${ }^{210} \mathrm{Po}$ (Heyraud \& Cherry 1979) in seawater are accumulated rapidly by the hepatopancreas of crustaceans and are often stored therein in the form of intracellular granules (Walker et al. 1975, Coombs \& George 1978, Gibson \& Barker 1979). 


\section{Elimination of ${ }^{237} \mathrm{Pu}$ and ${ }^{241} \mathrm{Am}$ in Carcinus maenas}

The elimination of ${ }^{237} \mathrm{Pu}$ and ${ }^{241} \mathrm{Am}$ from Carcinus maenas was slower than the elimination of ${ }^{237} \mathrm{~Np}$ from the shrimp Lysmata seticaudata (Guary \& Fowler 1977. 1978). In the shrimp, almost $90 \%$ of the incorporated neptunium was rapidly eliminated with a half-time of ca $4 \mathrm{~d}$. Despite differences in the chemistry of the radionuclides, the more rapid radionuclide loss from shrimp is related to the moulting frequency. Approximately $50 \%$ of the incorporated neptunium was lost from $L$. seticaudata with the first moult. Likewise, $L$. seticaudata contaminated with ${ }^{237} \mathrm{Pu}$ lost $42 \%$ of the radionuclide at moult (Fowler et al. 1975). The amount eliminated with the moult may vary depending upon the crustacean species. For example, a smaller planktonic crustacean, the euphausiid Meganyctiphanes norvegica, moults at approximately weekly intervals and loses as much as 42 to $63 \%{ }^{237} \mathrm{Pu}$ (Fowler unpubl.) and 70 to $90 \%{ }^{252} \mathrm{Cf}$ (Aston \& Fowler 1983) with its moult. Transuranic elements behave like many trace elements in that they are strongly associated with the exoskeleton of crustaceans (Fowler 1977, 1982). Thus, cast moults of some benthic decapods represent an important vector in the biogeochemical cycling of transuranics in the marine environment, their relative importance being a direct function of the moulting frequency of the species.

Evidently the crustaceans Carcinus maenas and Lysmata seticaudata (Guary \& Fowler 1977, 1978) can eliminate transuranic elements by means other than moulting. This elimination pattern fits a double exponential model with a very rapid release component $\left(T_{b^{1 / 2}}=3\right.$ to $\left.5 \mathrm{~d}\right)$ and a slow release component $\left(T_{b^{1 / 2}}=\right.$ several weeks) suggesting the existence of at least 2 distinct pools of transuranics. The rapid release component possibly reflects the desorption of radionuclides from the external surface of tissues such as exoskeleton and gills. Bryan (1966) has demonstrated that a portion of the zinc accumulated by $C$. maenas is excreted rapidly through the gills. Similarly, gills have been shown to be the primary site for mercury and cadmium excretion in the crab Maia squinado (Wright 1978). The slow release component, on the other hand, most likely reflects the excretion of transuranic elements closely associated with subcellular entities in internal tissues like hepatopancreas, or with other organic components of the non-calcified layers of the exoskeleton. A study of the subcellular distribution of ${ }^{237} \mathrm{Pu}$ and ${ }^{241} \mathrm{Am}$ in the hepatopancreas of the crab Cancer pagurus has shown that these radionuclides penetrate into the cells of the digestive gland and are bound to inclusions of calcium phosphate (Guary \& Negrel 1981). Furthermore, incorporated transuranic nuclides such as plutonium have been observed to be excreted via feces and in dissolved form (Fowler \& Guary 1977). Various heavy metals such as $\mathrm{Zn}, \mathrm{Cu}, \mathrm{Mn}, \mathrm{Co}$ and $\mathrm{Hg}$ are excreted in the urine of decapods (Bryan 1976, 1984), thus a similar mechanism is possibly responsible for the soluble excretion of the transuranic radionuclides.

Increase or decrease in body weight during the course of the study could feasibly affect the radionuclide loss rate, particularly that for the compartment in which radionuclide elimination is slow. Weight changes were not rigorously followed in our longerterm excretion experiments; however, spot checks on selected non-moulting shrimp and crabs made at the start and end of depuration indicated that little or no growth occurred during the experiments.

The possible association of transuranic elements with the organic components of crustacean exoskeleton, like the mucopolysaccharides, is more hypothetical, given the relative impermeability of the noncalcified external layer (epicuticle) which is composed of lipids and lipoproteins. However, losses of salts by diffusion across the cuticle have been observed by Shaw (1961). Further, Digby (1967) believes that calcium and other ions, particularly cations, can be incorporated directly into the cuticle from water. Under these conditions, it is conceivable that certain transuranic elements could also penetrate by this route, perhaps bind to the mucopolysaccharides of the cuticle, and exit by the same route during the depuration phase.

\section{Transuranic element transfer via the food chain: role of hepatopancreas}

Our food chain experiments have clearly shown that $\mathrm{Pu}, \mathrm{Am}$ and $\mathrm{Np}$ are effectively incorporated into crustacean tissues after ingestion of labelled food and are probably associated with various organic compounds. All of the radionuclides accumulate initially in the digestive gland. Data presented in Table 5 show that the absorption efficiency for ${ }^{237} \mathrm{Pu}$ increases with the size of the crustaceans from about $10 \%$ in the small shrimp Lysmata seticaudata to about $33 \%$ in the shore crab Carcinus maenas and even 30 to $40 \%$ in the larger crab Cancer pagurus. More probably, increases in absorption efficiency are related to increases in the degree of complexity of the digestive system, and hence with reduction in food transit time. For example, in the case of ${ }^{241} \mathrm{Am}$, the absorption efficiency is about 2 times higher ( 10 to $29 \%$ ) in the more highly evolved crabs Pachygrapsus marmoratus, $C$. maenas and $C$. pagurus than in the shrimps $L$. seticaudata and Palaemon serratus ( 8 to $10 \%$ ). In general, the same is true for ${ }^{237} \mathrm{Pu}$. In contrast, comparison of the turnover rates of ${ }^{237} \mathrm{Pu}$ and ${ }^{241} \mathrm{Am}$ did not show any major differences between radionuclides and decapod species $\left(T_{b^{1 / 2}}=2\right.$ 
to $8 \mathrm{~d}$ ) except for C. pagurus (ca $20 \mathrm{~d}$ ). The results in Table 5 also show that the absorption efficiency and gut transit time for ${ }^{237} \mathrm{~Np}$ are comparable to those for $\mathrm{Pu}$ and $A m$ in $C$. maenas.

Finally, transuranic retention in crustacean hepatopancreas clearly increases with body size, especially between the crabs Carcinus maenas and Cancer pagurus, even though this organ does not represent a substantially greater proportion of the body weight in the larger decapods tested. Thus, a relationship probably exists between hepatopancreatic retention of transuranic elements and the transit time of these elements through the digestive system, the latter being a function of the system's relative complexity. As has been shown for various radionuclides, the elimination rate is generally a function of the metabolic activity of the different species. For example, in small species with high metabolic rates and rapid egestion rates, enhanced radionuclide excretion is observed. In the case of transuranics, this is particularly noticeable between Lysmata seticaudata and $C$. pagurus. It becomes even more evident with small planktonic crustaceans which rapidly excrete ingested transuranics in a matter of hours (Fisher et al. 1983).

The absorption efficiencies for transuranics in marine decapods are extremely high when compared to the few tenths or hundredths of a percent generally assimilated by vertebrates (ICRP 1972), and significantly higher than the $1 \%$ of the more translocatable ${ }^{237} \mathrm{~Np}$ absorbed by the rat (Sullivan \& Crosby 1974). However, transuranic absorption is comparable to that of other radionuclides in marine crustaceans. For example, from a study by Odum \& Golley (1963) the absorption efficiencies for ${ }^{65} \mathrm{Zn}$ in marine isopods Idothea balthica ingesting labelled algae was estimated to be about $30 \%$. For Carcinus maenas ingesting labelled polychaetes, the absorption efficiency for ${ }^{60} \mathrm{Co}$ was nearly $50 \%$, with most of the radionuclide accumulating in the hepatopancreas (Amiard-Triquet \& Amiard 1974) Miramand et al. (1981) also showed that Lysmata seticaudata and Carcinus maenas which ingested food labelled with ${ }^{48} \mathrm{~V}$ assimilate $20 \%$ and $38 \%$ of the radionuclide, respectively. Even 1 mo after receiving the labelled food, ca $80 \%$ of the ${ }^{48} \mathrm{~V}$ body burden was located in the hepatopancreas of these 2 crustaceans.

According to Bryan $(1976,1984)$ and Wright (1978) numerous trace elements (e.g. Cu, Fe, $\mathrm{Zn}, \mathrm{Cd}, \mathrm{Mn}, \mathrm{Co}$ ) are commonly absorbed by marine crustaceans with efficiencies greater than 30\% (except for homarids), and are subsequently stored in the hepatopancreas primarily in the form of intracellular granules. The relatively high degree of transuranic absorption by marine decapods may be explained by at least 2 facts: First, most of the decapods are omnivores or carnivores and as such, have assimilation efficiencies for organic matter of ca 80 to $90 \%$ (Soldatova et al. 1969, Forster \& Gabbot 1971. Condrey et al. 1972). Consequently the absorption of radionuclides bound to metabolizable nutritive compounds is facilitated. Second, there is strong retention of transuranic elements in the digestive gland and, consequently, the overall excretion of these radionuclides is relatively slow compared to that in vertebrates.

Clearly the decapod hepatopancreas plays an extremely important role in the storage of trace elements including transuranium nuclides following their ingestion. Whatever the decapod species, between 40 to $100 \%$ of the absorbed transuranic radionuclide is associated with the digestive gland. Moreover, the major fraction of Pu and Am (50 to $60 \%$ ) is associated with calcium phosphate granules in the hepatopancreatic cells of Cancer pagurus (Guary \& Negrel 1981). Furthermore, the Pu present in the cytoplasmic fraction is bound to low molecular weight proteins which may belong to the metallothionein group. As in the case of iron, Pu in the hemolymph of crabs also appears to be associated with a circulatory protein which may be hemocyanin (Guary \& Negrel 1980). Thus, transuranium elements bound to these proteins are possibly transported internally to other tissues such as gonads, muscle and exoskeleton. This transfer appears to be quite rapid judging by the very small amount of transuranic elements found in the hemolymph after contamination. In this respect, $\mathrm{Np}$ seems more mobile than Am and the latter more so than Pu.

Under conditions of chronic food chain labelling with ${ }^{241} \mathrm{Am}$, the transuranic nuclide is rapidly taken up, transferred internally and accumulated in the majority of the tissues. After ca $80 \mathrm{~d}$, an equilibrium in the body burden is reached suggesting elimination is proceeding at a similar rate to uptake. Unfortunately, under these experimental conditions, it was impossible to measure the absorption efficiency toward the end of the experiment and thus, difficuit to tell whether the steady state in net accumulation was due to decreases in absorption efficiency or increases in radionuclide excretion rate with time.

Depuration of tissue-bound transuranics from decapods may be a function of 2 possible modes of excretion: (1) the extrusion of B-cells from the hepatopancreatic tubules toward the tubule lumen as described for Carcinus maenas by Hopkin \& Nott (1980), and (2) the extrusion of microgranules present in large amounts especially in the R-cells of the hepatopancreatic tubules of certain decapods (Hopkin \& Nott 1979). Transuranium nuclides may be eliminated by the first mode at the beginning of the organism's intermoult cycle before calcium is stored in sufficient levels in the hepatopancreas (Guary et al. umpubl.). Following ecdysis when the decapods are again calcified and the 
number of microgranules has greatly increased in the hepatopancreas, the transuranics strongly associated with these micro-inclusions (Ca, P, Mg; Guary \& Negrel 1981) could then be extruded in to the tubule lumen along with the micro-inclusions. In support of this hypothesis is the fact that these microgranules in decapods appear to effectively sequester many heavy metals (Simkiss 1976, Hopkin \& Nott 1979, Guary \& Negrel 1981). This proposed excretion mechanism in decapods is thus analogous to the processes of metal detoxication observed in other marine invertebrates (Coombs \& George 1978). Marine invertebrates eliminate many metals, previously concentrated in the kidney or digestive gland, by excretion of vesicules and granules. In the majority of the cases, these metal-containing granules are eventually extruded from the cells and transferred in to the lumen of the digestive gland, intestine or other excretory organs (Simkiss 1976).

Acknowledgements. The International Laboratory of Marine Radioactivity (ILMR) operates under an agreement between the International Atomic Energy Agency and the Government of the Principality of Monaco. We thank the Musée Océanographique at Monaco for support and the crew of the RV 'Physalie for collection of animals. Critical comments from $M$. Bernhard, C. Nolan and 2 anonymous reviewers substantially improved the manuscript and are greatly appreciated.

\section{LITERATURE CITED}

Amiard-Triquet, C., Amiard, J. C. (1974). Contamination de chaines trophiques marines par le cobalt-60. Revue int. Océanogr méd. 33: 49-59

Aston, S. R., Fowler, S. W (1983). Preliminary observations on californium-252 behavior in seawater, sediments and zooplankton. Health Phys. 44: 359-365

Beasley, T M., Cross, F. A. (1980). A review of biokinetic and biological transport of transuranic radionuclides in the marine environment. In: Hanson, W C. (ed.) Transuranic elements in the environment. National Technical Information Service, Springfield, Va., p. 524-540

Benayoun, G., Fowler, S. W (1980). Long-term observations on the moulting frequency of the shrimp Lysmata seticaudata. Mar Biol. 59: 219-233

Bowen, V T. (1974). Transuranic elements and nuclear wastes Oceanus 18: 43-54

Bryan, G. W. (1966). The metabolism of $\mathrm{Zn}$ and ${ }^{65} \mathrm{Zn}$ in crabs, lobsters and freshwater cray fish. In: Radioecological concentration processes. Pergamon Press, Oxford. p. 1005-1016

Bryan, G. W. (1976). Heavy metal contamination in the sea. In: Johnston, R. (ed.) Marine pollution. Academic Press, London, p. 185-302

Bryan, G. W. (1984). Pollution due to heavy metals and their compounds. In: Kinne, O. (ed.) Marine ecology, Vol. V (3). Wiley and Sons Ltd, Chichester, p. 1289-1431

Carvalho, F. P., Fowler, S. W. (1984). Experimental studies on biokinetics of americium in benthic marine organisms. In: Cigna, A., Myttenaere, C. (eds.) International symposium on the behaviour of long-lived radionuclides in the marine environment, EUR 9214. CEC, Luxembourg, p. 297-315
Carvalho, F. P., Fowler, S. W (1985). Biokinetics of plutonium, americium and californium in the marine isopod Cirolana borealis with observations on its feeding and molting behavior Mar Biol. 89: 173-181

Condrey, R. E., Gosselink, J. G., Bennett, H. J. (1972). Comparison of the assimilation of different diets by Penaeus setiferus and P. aztecus. Fish. Bull. U.S. 70: 1281-1292

Coombs, T. L., George, S. G. (1978). Mechanism of immobilization and detoxication of metals in marine organisms. In. McLusky, D. S., Berry, A. J. (eds.) Physlology and behaviour of marine organisms. Pergamon Press, Oxford, p. 179-187

Day, J. P., Cross, J. E. (1981). ${ }^{241}$ Am from decay of ${ }^{241} \mathrm{Pu}$ in the Irish Sea. Nature, Lond. 292: 43-45

Digby, P. S. B. (1967). Calcification and its mechanism in the shore-crab, Carcinus maenas (L.). Proc. Linn. Soc. Lond. 178: $129-146$

Edgington, D. N. (1981). Characterization of transuranic elements at environmental levels. In: Techniques for identifying transuranic speciation in aquatic environments. International Atomic Energy Agency, Vienna, p. 3-25

Fisher, N. S., Bjerregaard, P., Fowler, S. W. (1983). Interactions of marine plankton with transuranic elements. 3. Biokinetics of americium in euphausiids. Mar. Biol. 75: 261-268

Forster, J. R. M., Gabbot, P. A. (1971). The assimilation of nutrients from compounded diets by the prawns Palaemon serratus and Pandalus platyceros. J. mar. biol. Ass. U.K. 51 : 943-961

Fowler, S. W (1977). Trace elements in zooplankton particulate products. Nature, Lond. 269: 51-53

Fowler, S. W. (1982). Biological transfer and transport processes. In: Kullenberg, G. (ed.) Pollutant transfer and transport in the sea, Vol. II, Ch. 1 CRC Press, Boca Raton Florida, p. 1-65

Fowler, S. W., Aston, S. R. (1982). Application of ${ }^{235} \mathrm{~Np}$ in experimental aquatic radioecology: preliminary observations on neptunium behaviour in seawater, sediments and zooplankton. Health Phys. 42 (4): 515-520

Fowler, S. W., Carvalho, F. P. (1985). A mericium blokinetics in benthic organisms as a function of feeding mode. Bull. environ. Contam. Toxicol. 35 (6): 826-834

Fowler, S. W., Guary, J. C. (1977). High absorption efficiency for ingested plutonium in crabs. Nature, Lond. 266 (5605): $827-828$

Fowler, S. W., Heyraud, M., Beasley, T M. (1975). Experimental studies on plutonium kinetics in marine biota. In Impacts of nuclear releases into the aquatic environment. International Atomic Energy Agency, Vienna, p. 157-177

Gibson, R., Barker. P. L. (1979). The decapod hepatopancreas. Oceanogr. mar. Biol. A. Rev. 17: 285-346

Guary, J. C. (1980). Recherches sur le transfert et la fixation du plutonium, de l'americium et du neptunium dans le milieu marin. Thèse Doct.-ès-Sciences, Université d'Aix-Marseille II

Guary, J. C., Fowler, S. W. (1977). Biokinetics of neptunium237 in mussels and shrimp. Mar. Sci. Communs 3; 211-229

Guary, J. C., Fowler, S. W (1978). Uptake from water and tissue distribution of neptunium-237 in crabs, shrimp and mussels. Mar. Pollut. Bull. 9: 331-334

Guary, J. C., Fowler, S. W. (1981). Americium-241 and plutonium-237 tumover in mussels (Mytilus galloprovincialis) living in field enclosures. Estuar cstl Shelf Sci. 12 (2): 193-203

Guary, J. C., Masson, M., Fraizier, A. (1976). Etude préliminaire in situ de la distribution du plutonium dans différents tissus et organes de Cancer pagurus (Crustacea: Decapoda) et de Pleuronectes platessa (Pisces: Pleuronectidae). Mar Biol. 36: 13-17 
Guary, J. C., Negrel, R. (1980). Plutonium and iron association with metal-binding proteins in the crab Cancer pagurus (L.). J. exp. mar Biol. Ecol. 42: 87-98

Guary, J. C., Negrel, R. (1981). Calcium phosphate granules: a trap for transuranics and iron in crab hepatopancreas. Comp. Biochem. Physiol. 68A: 423-427

Hetherington, J. A. (1976). The behavior of plutonium nuclides in the Irish sea. In: Miller, M. W. Stannard, J. N. (eds.) Environmental toxicity of aquatic radionuclides: models and mechanisms. Ann Arbor Science Publishers, Inc., Ann Arbor, Michigan, p. 81-106

Hetherington, J. A., Jefferies, D. F., Mitchell, N. T., Pentreath, R. J., Woodhead, D. S. (1976). Environmental and public health consequences of the controlled disposal of trans uranic elements to the marine environment. In: Transuranium nuclides in the environment. International Atomic Energy Agency, Vienna, p. 139-154

Heyraud, M., Cherry, R. D. (1979). Polonium-210 and lead-210 in marine food chains. Mar. Biol. 52: 227-236

Hopkin. S. P., Nott, J. A. (1979). Some observations on concentrically-structured, intracellular granules in the hepatopancreas of the shore crab Carcinus maenas (L.). J. mar biol. Ass. U.K. 59: 867-877

Hopkin, S. P., Nott, J. A. (1980). Studies on the digestive cycle of the shore crab Carcinus maenas (L.) with special reference to the $B$ cells in the hepatopancreas. J. mar biol. Ass. U.K. 60: 891-907

ICRP (1972). The metabolism of compounds of plutonium and other actinides. In: International commission on radiological protection, Publ. Series 19. Pergamon Press, Oxford

Martin, J. L. M. (1975). Recherches sur le métabolisme des métaux chez les crustacés decapodes marıns; leurs rapports avec la mue et la reproduction. These Doct.-èsSciences naturelles, Université d'Aix-Marseille II

Miramand, M., Germain, P., Trilles, J. P. (1989). Histo-autoradiographic localization of americium $\left({ }^{241} \mathrm{Am}\right\}$ in tissues of the European lobster Homarus gammarus and the edible crab Cancer pagurus after uptake from labelled sea water. Mar. Ecol. Prog. Ser. 52: 217-225

Miramand, P., Guary, J. C., Fowler, S. W (1981). Uptake, assimilation and excretion of vanaduum in the shrimp Lysmata seticaudata (Risso) and the crab Carcinus maenas (L.). J. exp. Mar. Biol, Ecol. 49: 267-287

Odum, E. P., Golley, F. B. (1963). Radioactive tracers as an aid to the measurement of energy flow at the population level

This article was submitted to the editor in nature. In: Schultz, V., Klement, A. W (eds,) Radioecology. Reinhold Publ. Corp., New York, p. 403-410

Pentreath, R. J. (1981). The biological avallability to marine organisms of transuranium and other long-lived nuclides. In: Impacts of radionuclide releases into the marine environment. International Atomic Energy Agency, Vienna, p. 241-272

Perkins, R. W. Thomas, C. W. (1980). Worldwide fallout. In: Hanson, W. C. (ed.) Transuranic elements in the environment. Technical Information Center, U.S. Dept of Energy, p. $53-82$

Schulz, W W., Benedict, G. E. (1972). Neptunium-237: production and recovery. In: AEC critical review series, TID25955. Atlantic Richfield Hanford Co., Richland

Shaw, J. (1961). Studies on ionic regulation in Carcinus maenas (L.). Sodiurn balance. J. exp. Biol. 38: 135-152

Sibley, T. H., Sanchez, A. L. (1986). Why do Pu (III + IV) and $\mathrm{Pu}$ (V + VI) behave similarly in marine environments? J. environ. Radioact. 3: 75-78

Simkiss, K. (1976). Intracellular and extracellular routes in biomineralization. In: Duncan, C. J. (ed.) Calcium in biological systems. Symp. Soc. Expl Biol. 30. Cambridge University Press, Cambridge, p. 423-444

Soldatova, I. N., Tsikhon-Lukanina, Y A., Nikolayeva, G. G., Lukasheva, T A. (1969). The conversion of food energy by marine crustaceans. Okeanologiya 9: 875-882

Sullivan, M. F., Crosby, A. L. (1974). Absorption of uranium233, neptunium-237, plutonium-238, americium-241, curium-244 and einsteinum-253 from the gastrointestinal tract of newborn and adult rats. BNWL-1950, Part 1 , Batelle Pacific Northwest Lab., Richland, p. 105-108

Travis, D. F. (1955). The molting cycle of the spiny lobster Panulirus argus Latrelle. II. Pre-edcysial histological and histochemical changes in the hepatopancreas and integumental tissues. Biol. Bull. mar biol. Lab., Woods Hole 108: 88-112

Walker, G., Rainbow, P. S., Foster, P., Holland, D. L. (1975). Zinc phosphate granules in tissue surrounding the midgut of the barnacle Balanus balanoides. Mar Biol. 33: 161-166

Ward, E. E. (1966). Uptake of plutonium by the lobster Homarus vulgaris. Nature, Lond. 209: 625-626

Watters, R. L., Hakonson, T E., Lane, L. J. (1983). The behavior of actinides in the environment. Radiochim. Acta 32: 89-103

Wright, D. A. (1978). Heavy metal accumulation by aquatic invertebrates. Applied Biol. 3: 331-394

Manuscript first received: January 23, 1989

Revised version accepted: October 25, 1989 